\title{
(10) NNSA
}

\section{NATIONAL NUCLEAR SECURITY ADMINISTRATION}

\section{Nonproliferation Graduate}

\section{Fellowship Program}




\section{Fellows Talk About their NGFP Experience}

...part of a team with a tremendous sense of mission...

...supervisors put a great deal of in me and took my suggestions seriously...

...have proven ... that I can perform critical and objective evaluations of multi-million dollar, multi-year
Developed strategic depth to supplement academic experience...

... will contribute to my future biodefense work as I am now familiar with controlled commodities and challenges facing WMD enforcement officials.

...greatly expanded my

...provided

perspectives that I would not have

acquired through any other fellowship

program or post-master's opportunity.

Cover Photo: Seated, left to right: Jonathan Levinson, Alicia Swift, Lauren Rutledge, Alison Goodsell, Michelle Dover, Sonal Joshi, Manuel Manriquez, Daniel Miller, Lindsey Minnema, Jared Carter. Standing, left to right: Nicholas Cavellero, Mara Cowan, Mari Gillogly, Laurence Lewis, Courtney Gavitt, Kyle Hartig, Matthew Duchene, Daniel Kadishson, Zachary Whetstone, Rosalyn Leitch, Thomas Agee, David Vermillion. Not pictured: Patrick Disney. 


\section{Building Leadership \\ for a More Secure World}

The mission of the National Nuclear Security Administration's (NNSA) Office of Defense Nuclear Nonproliferation is to detect, secure, and dispose of dangerous nuclear and radiological material, and related WMD technology and expertise. We play a crucial role in meeting President Obama's nuclear security agenda of preventing nuclear terrorism and securing fissile materials.

Through its 16-year history, our Nonproliferation Graduate Fellowship Program (NGFP) has had one purpose: to prepare the next generation of experts in nuclear security and nonproliferation. We are proud of the results. Since NGFP began in 1997, 243 NGFP alumni have continued to apply the knowledge and experience they gained at NNSA inside and outside of the organization. Some of them have risen to levels of responsibility where they are making key decisions on behalf of our nation. This continuing pipeline of highly qualified young professionals will help sustain expertise in this area for decades to come.

The contributions of the Class of 2012 were truly impressive-from briefing the Secretary of Energy, to helping manage nonproliferation projects in collaboration with partner countries, to planning and contributing to international technical workshops. As these Fellows represented NNSA to agency partners,

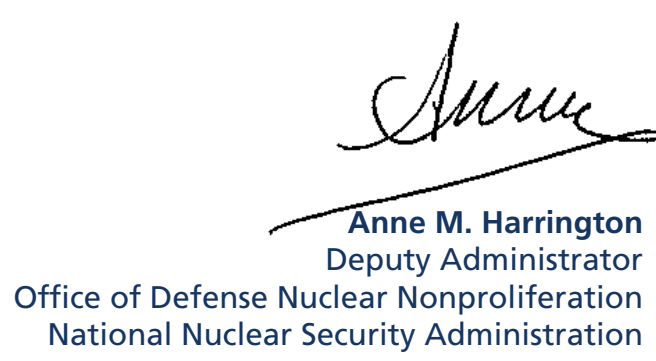

industry, and nongovernment organizations, they also reaffirmed NNSA's crucial mission and role in the broader nuclear security community.

I consider this program one of the most successful of its kind, not only in the U.S. Department of Energy, but possibly in all of government. I credit this to strategic university relationships, best-practices management and execution, and our hands-on support that follows the Fellows throughout their assignments. And of course, our Fellows deserve the most credit. By applying their impressive backgrounds, they make their own unique contributions.

The Class of 2012 has a special role because it marks the close of the NGFP. With the incoming Class of 2013, we've combined the best traits of NGFP with our former Future Leaders Program to serve the entire NNSA enterprise. This consolidated NNSA Graduate Program stays true to our core purpose: providing opportunities for the nation's best and brightest to advance the nuclear security and nonproliferation mission.

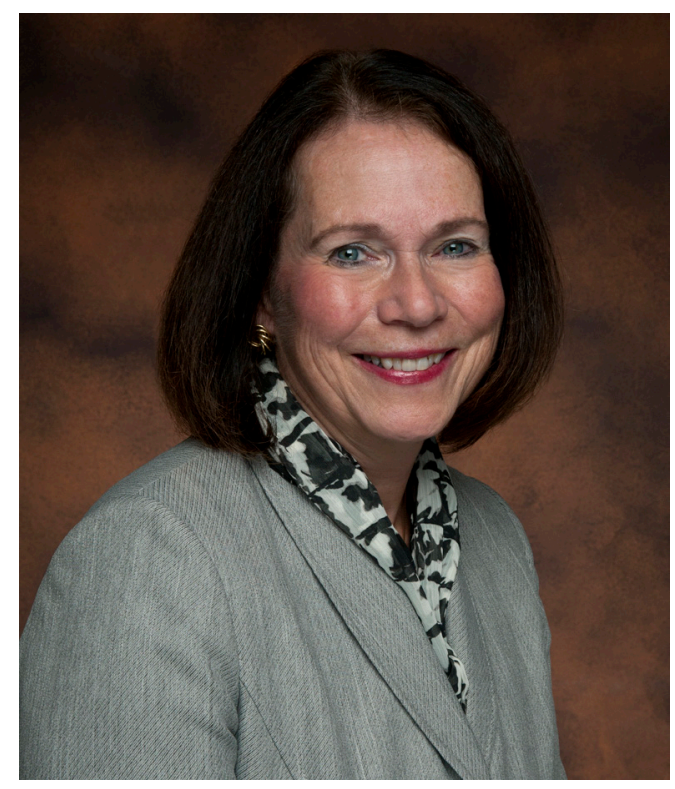




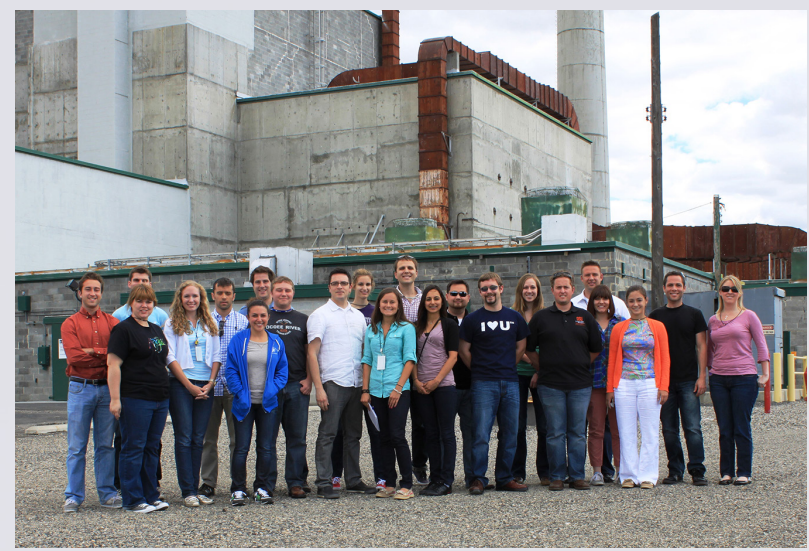

The Class of 2012 stands in front of the world's first operating reactor, at the Hanford Site in Washington state.

The mission of the Nonproliferation Graduate Fellowship Program (NGFP) is to produce exceptional leaders in nonproliferation and international security. In support of this mission, NGFP managed and completed activities for the Class of 2012. This included outreach to attract candidates, management of interviews, hiring, and providing career growth opportunities for the group throughout their year-long assignments from June 2012 through June 2013. Significant accomplishments included the following:

- Outreach and applicants. 225 qualified, advanceddegree candidates applied, 56 (25\%) more than the previous year. They represented 74 universities across the nation and from London, 26 of these universities represented for the first time. Those selected represented 16 universities, including five that were represented for the first time: Yale University, the University of California, Berkeley, the National Defense University, Pennsylvania State University, and the University of Illinois.

- Technical backgrounds. Nine Fellows, nearly $\mathbf{4 0 \%}$ of the class, had technical backgrounds, with master's or PhDs. Two more Fellows completed their PhDs in technical topics during their assignments. Such backgrounds are especially prized in NNSA for understanding and analyzing complicated technical issues.

- Placements. The 23 Fellows who were selected worked in six NNSA program offices and DOE's Office of Intelligence and Counterintelligence.
- Value to NNSA. Fellows made significant contributions in areas of policy, technology, and program management. They assisted in managing dozens of programs and projects, evaluated technical proposals, worked directly with representatives in the United States and partner countries, developed and presented at workshops and training events, helped prepare materials for Congress, and participated in radiation detection testing.

- Career development. NGFP sponsored five career growth events, where Fellows spoke with $\mathbf{1 8}$ diverse leaders from the security community about their missions and career opportunities. One of these events led directly to a job offer.

- Continuing the mission. Half of this year's alumni were hired in federal and support services contractor positions in NNSA and U.S. Department of Energy's national laboratories, increasing the next-generation talent pool. Other alumni continued their global security careers in other government agencies and industry, taking the NNSA perspective with them.

Through these accomplishments, NGFP is developing outstanding leaders who are dedicated to the NNSA mission: reducing the threat of nuclear terrorism worldwide.

NGFP achieved these measurements of success for the Class of 2012:

- Assisted NNSA in achieving its mission

- Promoted awareness of careers in nonproliferation at NNSA and U.S. Department of Energy national laboratories

- Provided participants with specialized training and valuable practical experience in the field of nonproliferation

- Developed a talent pool to support NNSA's international security and nonproliferation programs. 


\section{Contents}

Building Leadership for a More Secure World $\ldots \ldots \ldots \ldots \ldots \ldots \ldots \ldots \ldots$ iii

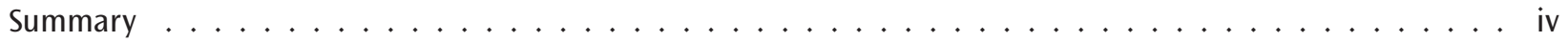

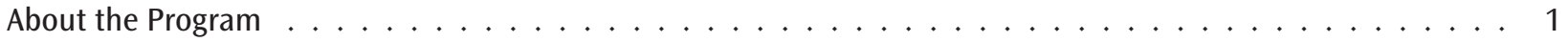

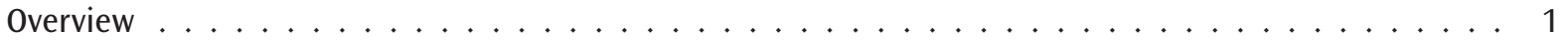

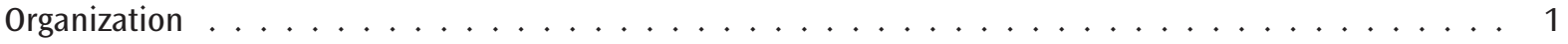

Annual Lifecycle and Report Scope . . . . . . . . . . . . . . . . . . . . . . . . . . 1

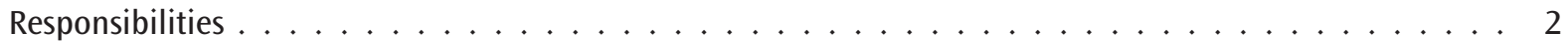

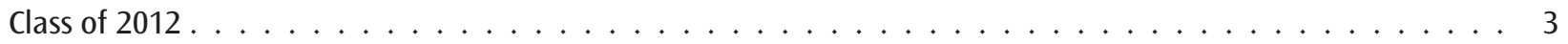

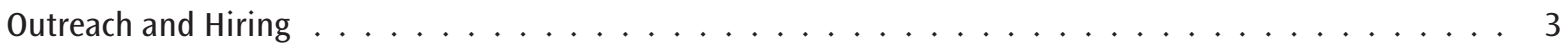

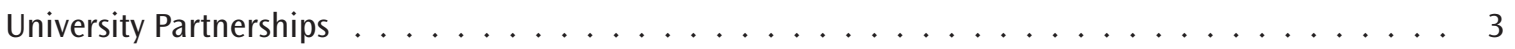

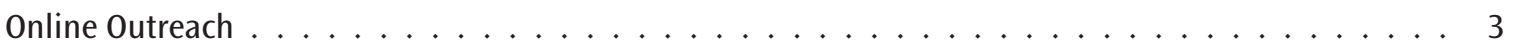

Outreach Results . . . . . . . . . . . . . . . . . . . . . . . . . . . . . 4

Interviews, Hiring, and Clearances. . . . . . . . . . . . . . . . . . . . . . 4

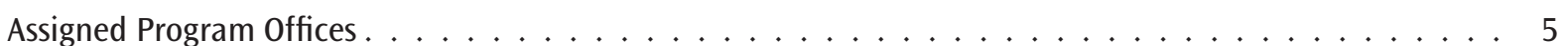

Orientation and Career Development $\ldots \ldots \ldots \ldots \ldots \ldots \ldots \ldots$

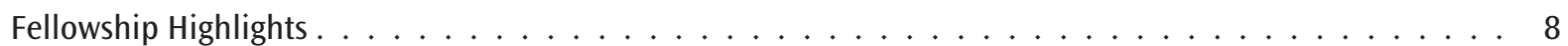

Where They Are Now . . . . . . . . . . . . . . . . . . . . . . . . . . . . . . . . . 11

Alumni Spotlight . . . . . . . . . . . . . . . . . . . . . . . . . . . . . . . . . 12

Appendix: Class of 2012 Biographies . . . . . . . . . . . . . . . . . . . . . . . . . . . . 15 


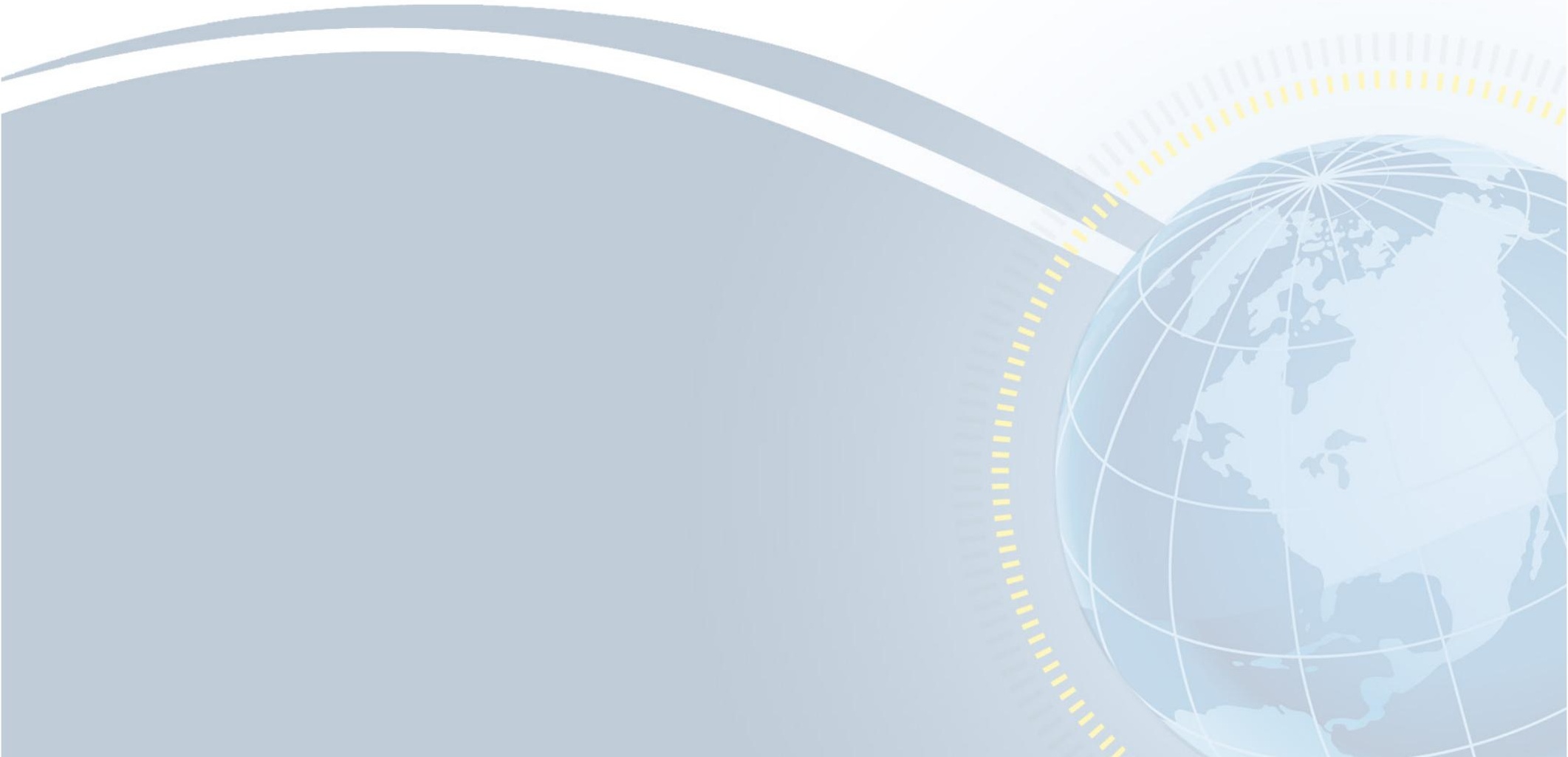




\section{About the Program}

\section{Overview}

The Nonproliferation Graduate Fellowship Program (NGFP) is a National Nuclear Security Administration (NNSA) program with a mission to cultivate future leaders in nonproliferation and international security. Through the NGFP, outstanding graduates with career interests in nonproliferation are appointed to Program Offices within the Office of Defense Nuclear Nonproliferation. During their one-year assignment, Fellows participate in programs designed to detect, prevent, and reverse the proliferation of nuclear weapons.

\section{Organization}

The NGFP is managed through NNSA's Office of Management and Budget and administered by Pacific Northwest National Laboratory (PNNL), with roles shown in the chart to the right.

\section{Annual Lifecycle and Report Scope}

Each year, the NGFP's annual lifecycle involves planning, administration, and implementation of three different fellowship classes: orienting and administering the current class of Fellows, attracting and hiring the next class, and university outreach planning for the future class. This annual report covers program activities for the Class of 2012, from outreach in summer 2011 through the assignment that began June 2012 and ended June 2013.

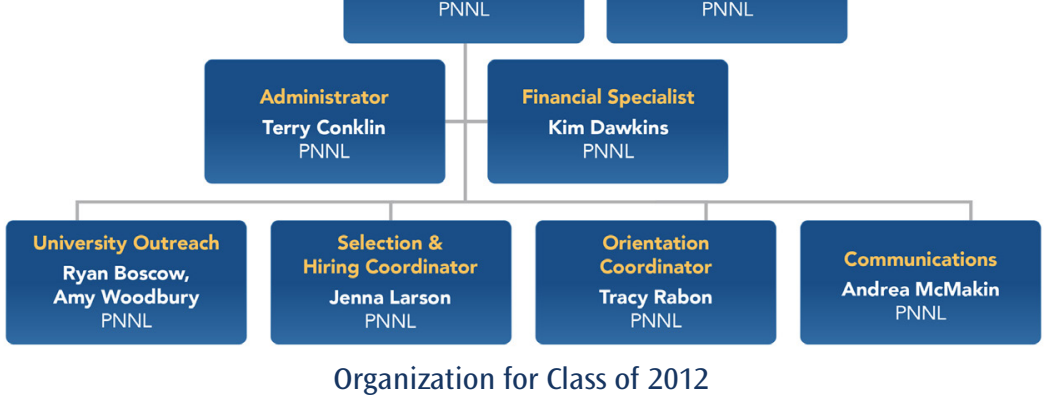

\section{Class of 2012 Lifecycle}

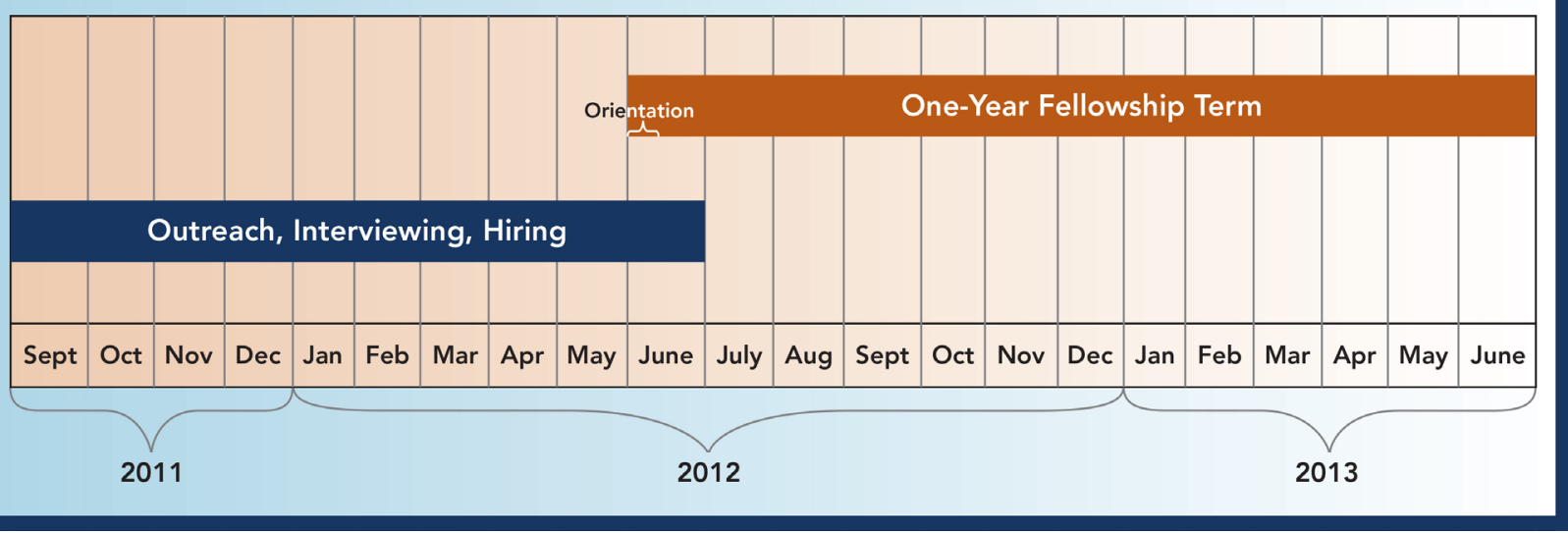




\section{Responsibilities}

The Federal and PNNL Program Managers share a unified approach based on a common vision and framework. The operational structure is organized into five program elements as shown in the figure below.

\section{Program Responsibilities}

Program

Management

Outreach

Selection \&

Hiring

Orientation \&

Training

Career

Development
Overseeing all aspects of the program, including the budget, strategy, stakeholder engagement, implementation, evaluation, issues resolution, improvements, and reporting.

Developing and implementing an outreach strategy to meet program objectives. This includes conducting a hiring needs assessment with NNSA offices requesting Fellows, partnering with universities and professional associations for outreach, working closely with prospective candidates to facilitate the application process, and maintaining the online application system.

Preparing applications for review by NNSA offices and sites, preparing for NNSA interviewing, hiring, and overseeing the security clearance process for selected Fellows.

Conducting an extensive orientation to prepare Fellows for their assignments and roles in the federal environment.

Introducing the Fellows to career growth opportunities through interactive sessions with professionals in the nuclear security field. 


\section{Class of 2012}

\section{Outreach and Hiring}

NGFP strategically applied its resources to yield the best candidates to achieve program goals. The program focused on universities that

- Met NNSA Program Office hiring needs

- Offered the nation's top academic programs in nonproliferation, security, international relations, and/or nuclear engineering

- Historically provided a significant percentage of NGFP's candidate pool

- Consistently worked to promote NGFP and are established partners

- Showed a commitment to student diversity. NGFP leveraged established university partnerships and professional associations, and formed new relationships based on the outreach criteria. NGFP outreach specialists used a variety of methods, including on-campus engagements, online outreach, and strategic connections through former NGFP Fellows and current stakeholders.

\section{University Partnerships}

Statistics show that information sessions and colloquia held at universities are the single most significant way applicants become aware of the program. Career fairs at strategically selected schools and with professional associations reach a broader audience; they also increase visibility and interest in NNSA's mission. For the Class of 2012, NGFP participated in 26 outreach events at universities that met the program's criteria. PNNL formed new recruiting relationships with Stanford University, University of Maryland, University of Nevada Las Vegas, and University of Tennessee.

Several other methods of outreach developed and strengthened university partnerships, broadened NGFP's reputation, and increased general interest in the mission. Student groups from three universities visited NNSA headquarters, and NGFP outreach specialists were invited to speak in four university classrooms. At Stanford University and the University of Michigan, visits included meetings with administrators, faculty, and students.

\section{Online Outreach}

A significant number of applications-17\% - came in from online outreach. The NGFP website is updated regularly to provide current information and give guidance throughout the application process. In addition, NGFP engaged 61 universities and associations with mission-relevant program through an online tracking and scheduling system. Including the NGFP's presence on these university websites vastly expands the program's outreach with minimal cost.

\section{Outreach Results}

Guided by a proven outreach strategy, NGFP increased applicants by $33 \%$, with 225 completed applications compared with 169 in the previous year. Fifty of the current year's applicants boasted advanced technical degrees, with 23 of those having PhDs or enrolled in PhD programs. This is a $44 \%$ increase in PhD applicants and a $56 \%$ increase in overall technical degrees from the previous year. As a result, NGFP delivered the largestyet slate of high-quality candidates that met Program office criteria.

The overall caliber of applicants to the Class of 2012 was reflected in this continuing upward trend: 32 applications were from top-tier nuclear engineering schools and 27 from top-tier political science schools, according to U.S. News \& World Report rankings.

The map on the next page shows the home universities of the 23 selected Fellows in the Class of 2012, including five that were represented for the first time: National Defense University, Pennsylvania State University, University of California-Berkeley, University of Illinois, and Yale University.

"I have applied to several fellowship programs over the years ... and found your application process to be one of the most streamlined, organized, and accessible."

A candidate 
The Class of 2012 hailed from 15 universities in the United States and the United Kingdom, including five that were represented for the first time.

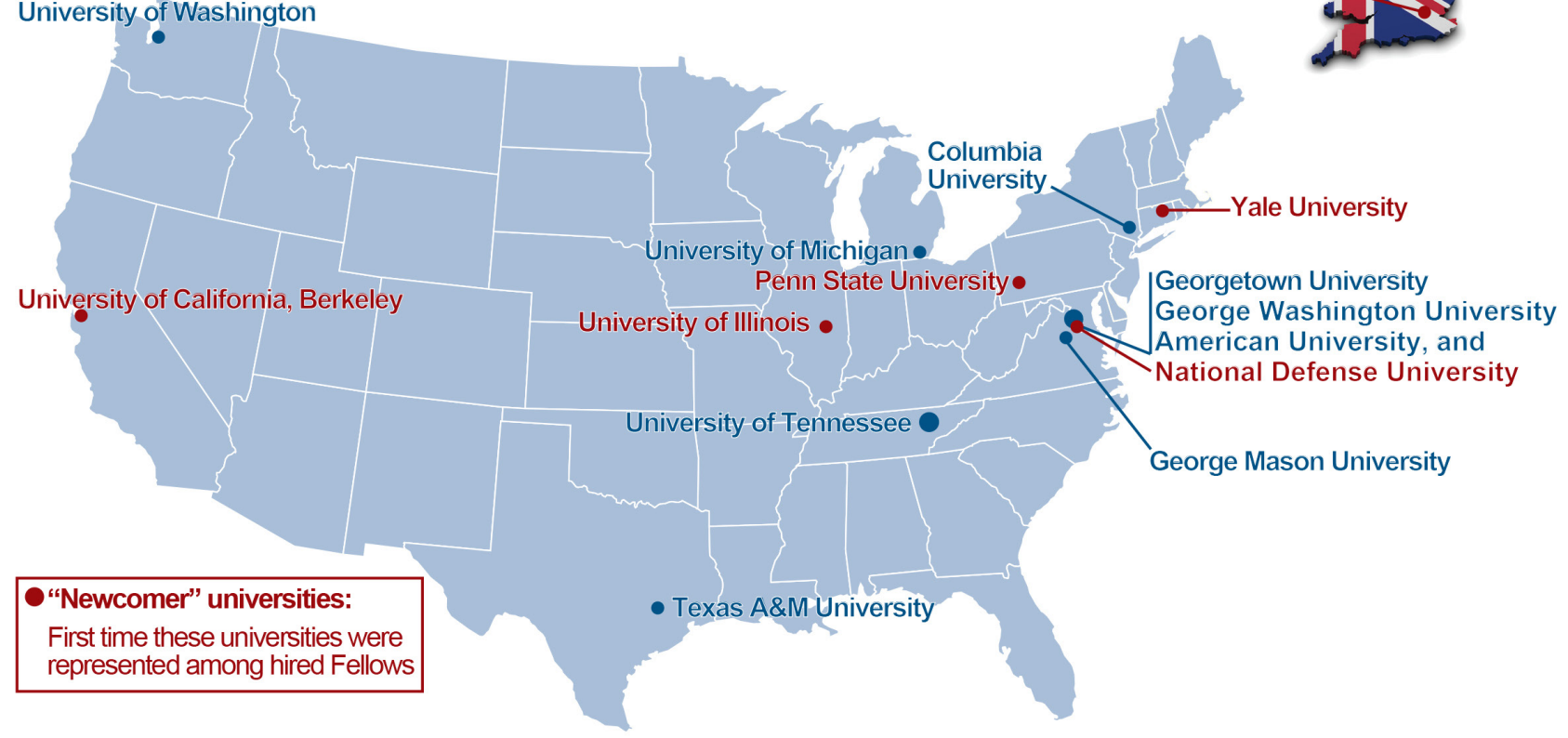

\section{Interviews, Hiring, and Clearances}

For the Class of 2012, Program Offices selected 79 interview candidates from 225 total applicants, or $35 \%$ of the total applications. Being able to choose the most promising interviewees from a pool of already high-quality candidates that met NGFP's criteria means Program Offices get the "cream of the crop."

NNSA Program Offices conducted a total of 136 interviews over the seven working days from November 26 through December 12, 2012. Sixteen Program Office teams chose to participate in this year's interview and selection process. Feedback from the NNSA Program Offices indicated they found the process to be very well organized, and candidates expressed gratitude for the team's assistance throughout the complex logistical process.

After the NNSA Program Offices selected their hiring choices, the Federal and PNNL Program Managers worked with NNSA Program Office team to assign candidates who were chosen by multiple offices, for a total of 23 Fellows hired.

As directed by the NNSA Federal Program Manager, NGFP Fellows are hired as employees of Battelle, the independent research organization that operates PNNL for the DOE. Thus, PNNL administers all pre-employment and employment activities for
NGFP, including pre-interview background checks, required drug testing, facilitation of security clearance processing for DOE's Chicago Office, and interview facilitation for NNSA. Hired Fellows enter with all their employment details completed, enabling them to "hit the ground running" in their assignments.

\section{"Really appreciate all your hard work screening these candidates, setting this up, and even shepherding them!! You guys make the process easy!"}

An NNSA program manager from the Office of Nuclear Security

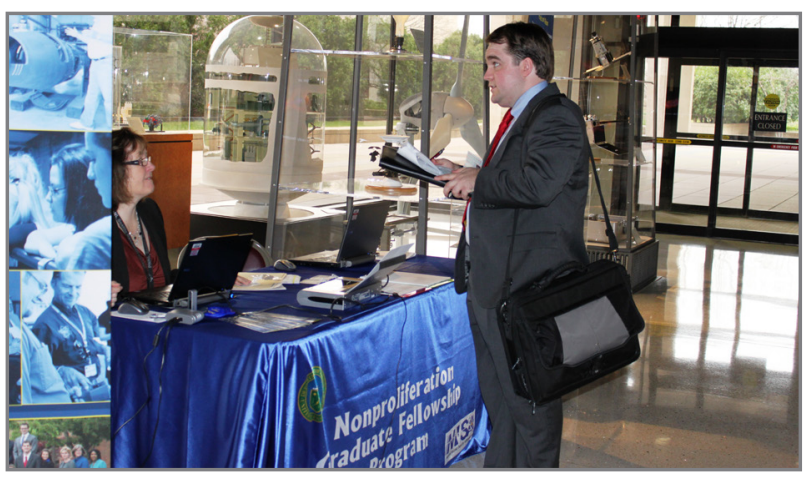

An interviewee gets instructions from NGFP team member Terry Conklin at NNSA headquarters in Washington, D.C. NNSA hiring managers from 16 Program Offices conducted a total of 136 interviews to select the Class of 2012. 


\section{Assigned Program Offices}

Program Offices carefully select Fellows whose combination of academic backgrounds, skills, and experience can make the most significant contribution to their mission areas.

The 23 participants who composed the Class of 2012 boasted the following impressive statistics:

- Placement in seven DOE NNSA Program Offices, including a Fellow serving in DOE's Office of Intelligence and Counterintelligence

- Ten advanced technical degrees in engineering and radiological sciences, including four $\mathrm{PhD}$ candidates

- Previous positions with the White House, U.S. Departments of Energy, State, Defense, Homeland Security, and Commerce; U.S. Army (officer); U.S. Environmental Protection Agency; U.S. Nuclear Regulatory Commission; national laboratories; assistants to elected officials; nongovernment organizations; and the private sector

- Degrees from Columbia University, Yale University, the University of California, Berkeley, the National Defense University, and King's College London, among others

- Fluency in Arabic, Farsi, French, German, Hindi, Japanese, Russian, Spanish, and Turkish.

Individual biographies for the Class of 2012 are provided in the Appendix. The Class of 2012 participants and their assigned Program Offices were:

Thomas Agee: Office of Global Threat Reduction, North and South American Threat Reduction

Jared Carter: Office of the Second Line of Defense Megaports

Nicholas Cavellero: Office of Former Soviet Union and Asian Threat Reduction

Mara Cowan: Office of European and African Threat Reduction

Patrick Disney: Office of Nonproliferation and International Security
Michelle Dover: Office of Nuclear Safeguards and Security, Safeguards Policy

Matthew Duchene: Office of Defense Nuclear Nonproliferation Research and Development

Courtney Gavitt: Office of Nuclear Controls, Export Control Review and Compliance Team

Mari Gillogly: Office of Nuclear Safeguards and Security, Safeguards Engagement

Alison Goodsell: Office of Intelligence and Counterintelligence

Kyle Hartig: Office of Nuclear Safeguards and Security, Safeguards Technology

Sonal Joshi: Office of Defense Nuclear Nonproliferation Research and Development

Daniel Kadishson: Office of International Material

Protection and Cooperation

Rosalyn Leitch: Office of Nuclear Safeguards and Security, Nuclear Security

Jonathan Levinson: Office of Defense Nuclear Nonproliferation

Laurence Lewis: Office of European and African Threat Reduction

Manuel Manriquez: Office of Nuclear Controls, Global Initiatives for Proliferation Prevention Team

Daniel Miller: Office of Nuclear Controls, International Nonproliferation Export Control Program

Lindsay Minnema: Office of Nuclear Controls, International Nonproliferation Export Control Program

Lauren Rutledge: Office of Management and Budget

Alicia Swift: Office of North and South American Threat Reduction

David Vermillion: Office of Nonproliferation Verification Research and Development

Zachary Whetstone: Office of Defense Nuclear Nonproliferation Research and Development 


\section{Orientation and Career Development}

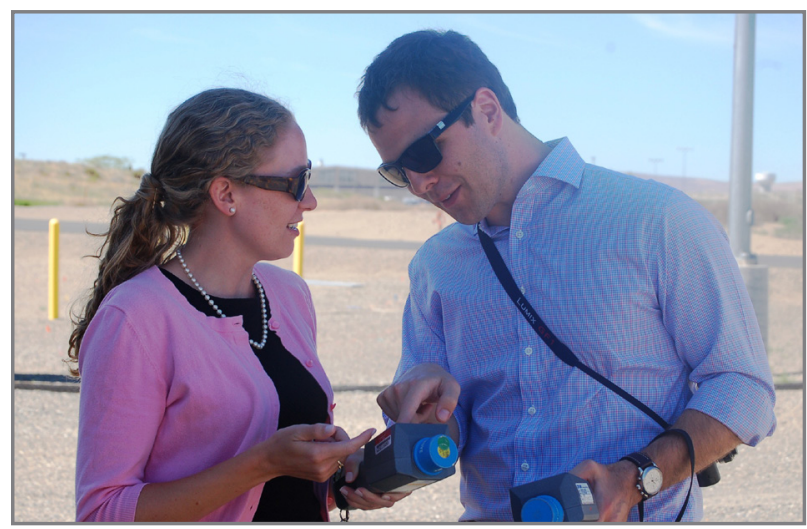

During NGFP orientation, Alicia Swift and Laurence Lewis compare radiation detection readouts during a nuclear detection exercise.

Orientation prepares the Fellows for success in their new roles and introduces them to the NGFP, the NNSA, and the DOE. Orientation was streamlined this year to include eight days of technical site tours, specialized training on working in a federal environment, roundtable discussions with PNNL program managers and technical staff who support NNSA programs, and briefings from NNSA leadership.

The first part of the orientation was at PNNL in Richland, Washington and the second part was at NNSA Headquarters in Washington, D.C. Immediately following the orientation at NNSA, Fellows began working in their assignments. Fellows were matched with "buddies" from the previous class who serve as informal mentors.

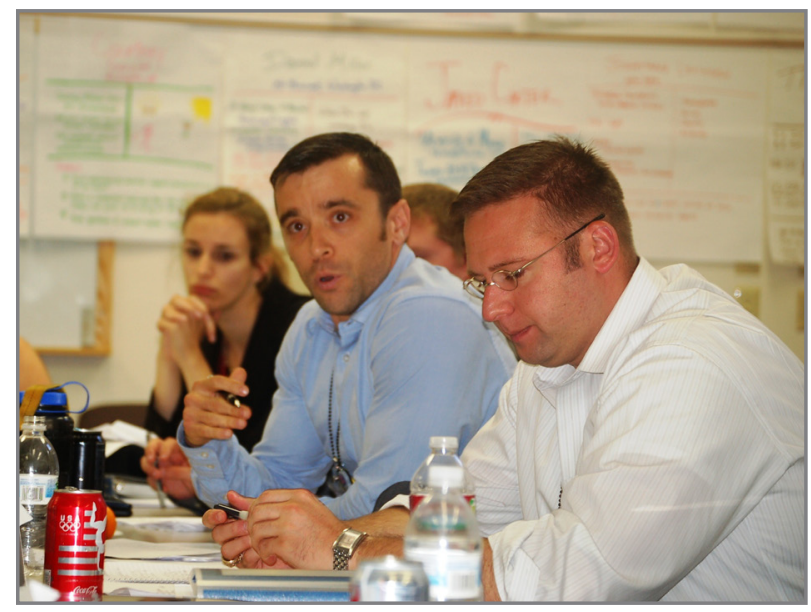

Jonathan Levinson, a five-year Army officer who led a platoon in Iraq, makes a point at a mock Senate hearing. The event simulated the give-and-take of a lively legislative interaction.

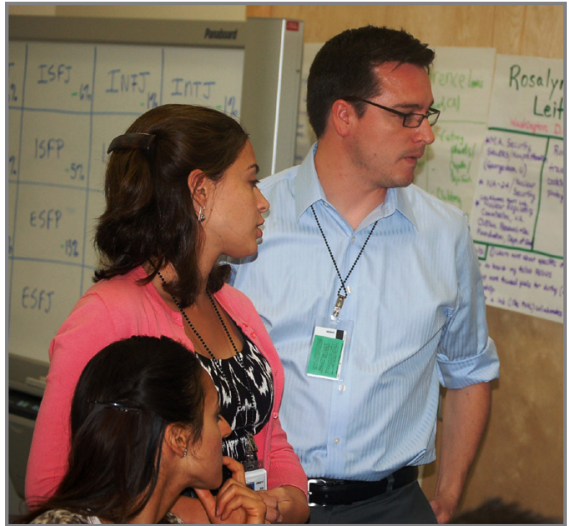

Fellows (left to right) Sonal Joshi, Michelle Dover, and Manuel Manriquez plan their strategy to accomplish a group task.

The NGFP is committed to creating opportunities for the Fellows' career advancements in fields related to nuclear security. Several improvements made this year's career development events even more valuable. These modifications were designed based on feedback from previous year's Fellows as well as the goal of expanding the understanding of the broader nuclear security community and NNSA's role in it.

First, more additional guest speaking events were scheduled, providing more opportunities to hear from a broader range of experts. Second, events were scheduled early in the year, enabling Fellows to have more time to follow up with guest speakers later in the year. Third, speakers participating in the Alumni Roundtable were scheduled for an additional period of informal, personalized interaction.

The Class of 2012 participated in the following career development events during their assignments:

- National Laboratories Roundtable (September 2012). Fellows heard from DOE national laboratory representatives about how each one supports the mission of nuclear security and nonproliferation. Fellows talked with the panelists about career advice and work at the laboratories. Participants included:

> Dr. Kirsten Laurin-Kovitz, Program Manager, Nonproliferation and National Security, Argonne National Laboratory

> Billy Marshall, Jr., Program Manager, International Nonproliferation and Arms Control Program, Sandia National Laboratories

> Dr. Nina D. Rosenberg, Deputy Program Director for Nuclear Nonproliferation and Security, Los Alamos National Laboratory 
, Dr. Robert Runkle, Nuclear Security Account Manager, Pacific Northwest National Laboratory

> Dr. Lawrence J. Satkowiak, Director of Global Security and Nonproliferation Programs, Oak Ridge National Laboratory

> Peter Vanier, Research Engineer, Nonproliferation and National Security Department, Brookhaven National Laboboratory.

- Alumni Roundtable (November 2012). Fellows received career planning insights from successful NGFP alumni in the corporate world as well as government. Participants included:

> Dr. Clark Cully, Policy Analyst, Office of Nuclear and Missile Defense Policy, Office of the Secretary of Defense

> Jessica Drum, Associate, Gryphon Scientific

> Dr. Peter Sprunger, Physical Scientist, Bureau of International Security and Nonproliferation, Department of State

, Ryan Taugher, Analyst with Computer Science Cooperation, contractor for the U.S. Department of State.

- Career Networkshop (January 2013). During the Career Networkshop, representatives from the following agencies and companies conducted informational interviews with the Fellows:

> Dr. Dorothy Davidson, Senior Vice President for Programs, AREVA Federal Services LLC

> Dr. Karen Henderson, Senior Level Foreign Policy Advisor, Office of International Programs, Nuclear Regulatory Commission

> Ryan Madden, Supervisory Physical Scientist, U.S. Department of Defense, Defense Threat Reduction Agency.

> Cary 0'Connell, Culmen International

> Anna Rapp, Country Councils and outreach Coordinator, Department of State Overseas Security Advisory Council

, Dr. Elizabeth Turpen, Independent consultant formerly with Booz Allen Hamilton.
"The Networkshop was among the most beneficial events we have had. It was great because we could ask questions about employment opportunities very freely and in my case, express interest in working at a few of the organizations that were represented. Everything went smoothly in terms of scheduling and meeting."

- A Fellow

Additional career development events. Based on feedback from Fellows and program offices, NGFP arranged the following events to introduce Fellows to additional opportunities.

> A roundtable was held on October 16, 2012 with Nick Carlson, NNSA's Office of International Operations, for Fellows to learn more about future career opportunities with the DOE Foreign Offices.

> On November 8, 2012, Brigadier General Julie Bentz, Director of Strategic Capabilities Policy at the National Security Council, spoke to the Fellows about career opportunities in the interagency.

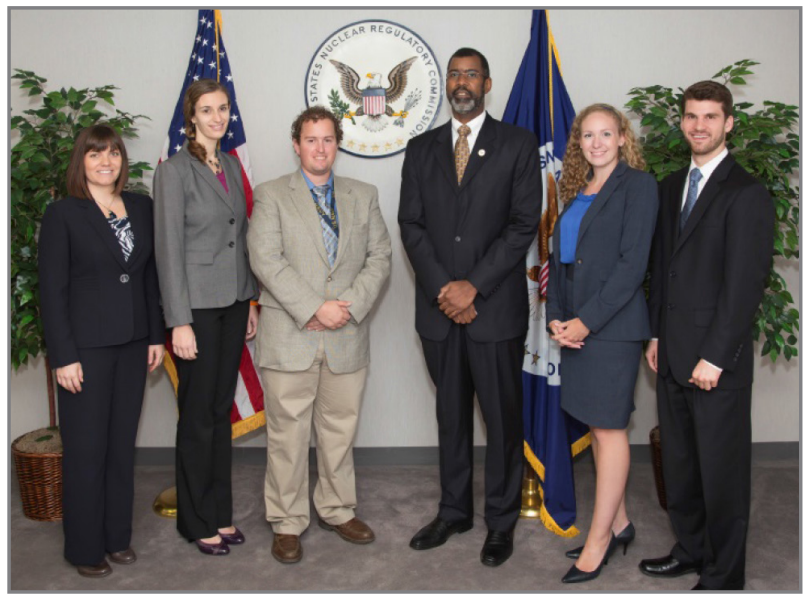

To better understand interagency roles, Fellows arranged a tour at the Nuclear Regulatory Commission Emergency Operations Center and discussed nuclear energy and nonproliferation issues with NRC Commissioner William Magwood (third from right). 


\section{Fellowship Highlights}

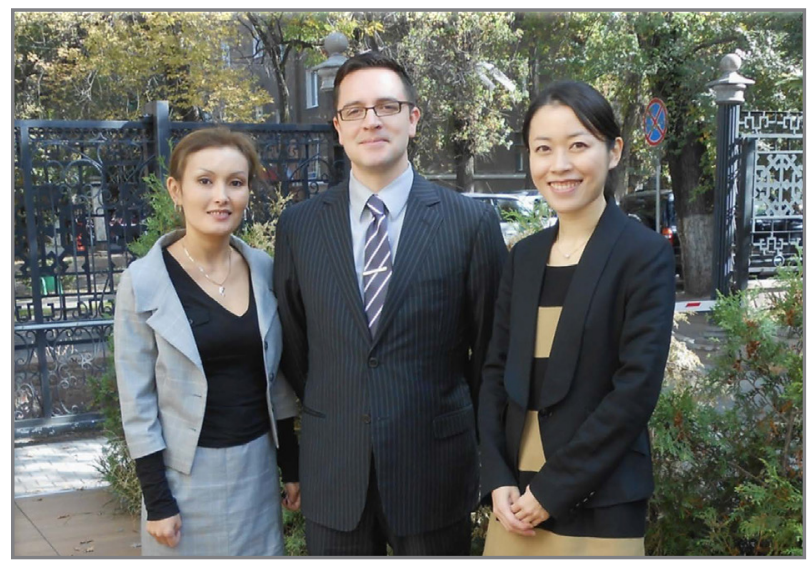

Manuel Manriquez stands with delegates from Kazakhstan and Japan at the International Science and Technology Center meeting in Kazakhstan.

Fellows are given significant mission responsibilities. Their value increases as they contribute in areas of policy, technology, and program management. Here are a few highlights from the Class of 2012:

- Safeguarding nuclear and radioactive sources from theft is the first line of defense in nonproliferation. Thomas Agee supported the implementation of physical protection upgrades at civilian nuclear and radiation sites in 19 countries. Rosalyn Leitch worked with NNSA laboratories and the Nuclear Regulatory Commission to support a database to prioritize bilateral physical protection assessment visits. Alicia Swift led a cost-savings study for NNSA's physical protection upgrade activities in the United States.

- NNSA works cooperatively with U.S. organizations and partner countries to advance nuclear security goals worldwide. Michelle Dover contributed to a U.S.-Russian safeguards consultation process.

Michelle Dover, Sonal Joshi, Mari Gillogly, Laurence Lewis, Rosalyn Leitch, and Lindsay Minnema helped plan and execute national and international events on ground-based nuclear detonation detection technologies, medical isotopes, safeguards, and nuclear forensics. Daniel Kadishson prepared negotiation strategy papers for the successor agreement to the U.S.-Russia Cooperative Threat Reduction agreement (the Nunn-Lugar agreement).

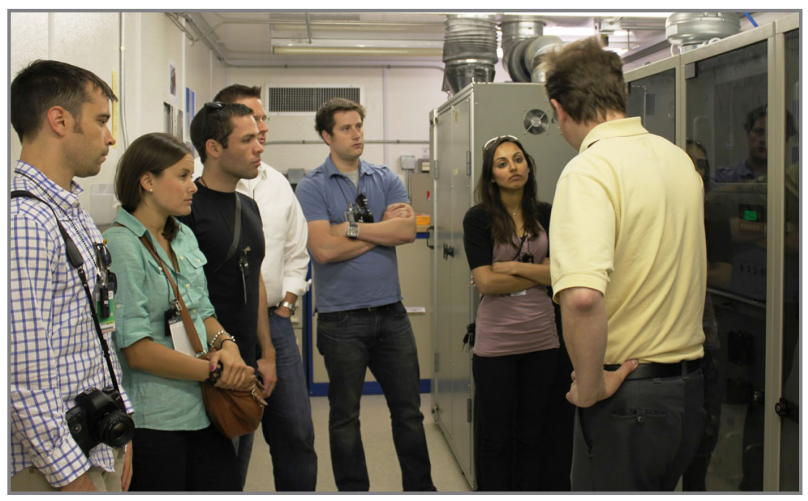

During their terms, participants got first-hand views of current technologies used in nonproliferation and counter-terrorism.

- Detection systems and new technologies help deter nuclear smuggling. Jared Carter coordinated detection system training and testing activities in partner countries. Kyle Hartig briefed Secretary of Energy Dr. Steven Chu on his PhD research in laser remote sensing. David Vermillion evaluated the technical merit of more than 100 research and development projects and proposals under the office of Proliferation Detection.

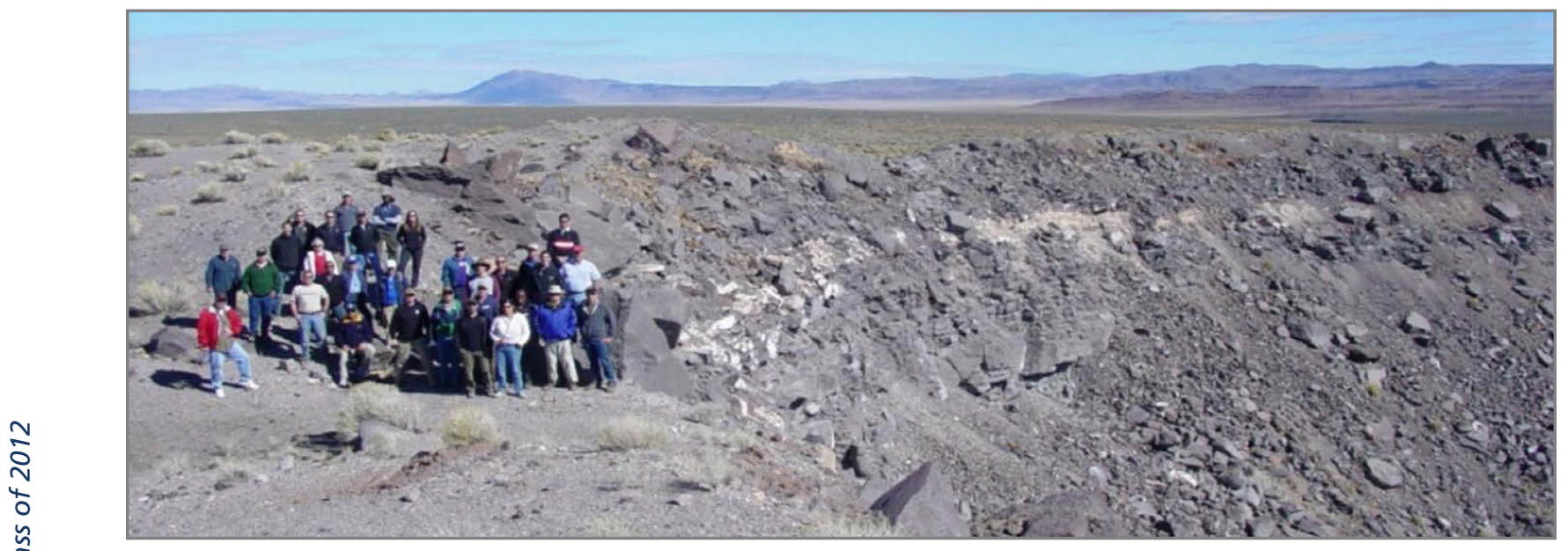

With colleagues from Los Alamos National Laboratory, a group of Fellows is dwarfed by a crater at the Nevada National Security Site. 
- Export controls help keep proliferation-sensitive commodities out of the wrong hands. Mari Gillogly served on a team that developed first-of-its-kind advanced training for intelligence community professionals on nonproliferation and export controls related to missile technologies. Courtney Gavitt developed an Export Control Handbook covering topics from domestic export license review to multilateral regime support. Daniel Miller conducted export control licensing and enforcement events with five countries.

- Some Fellows are responsible for managing programs and projects, and some develop tools for greater efficiency and collaboration. Patrick Disney supported the development of a five-year strategic plan for NNSA's forensics engagement program. Kyle Hartig led three research and development working groups, reviewing the progress of five national laboratories. Manny Manriquez managed research and development projects across four countries in the Former Soviet Union and Middle East. Lauren Rutledge prepared a five-year strategic plan for the Enterprise Modeling Consortium. Zach Whetstone

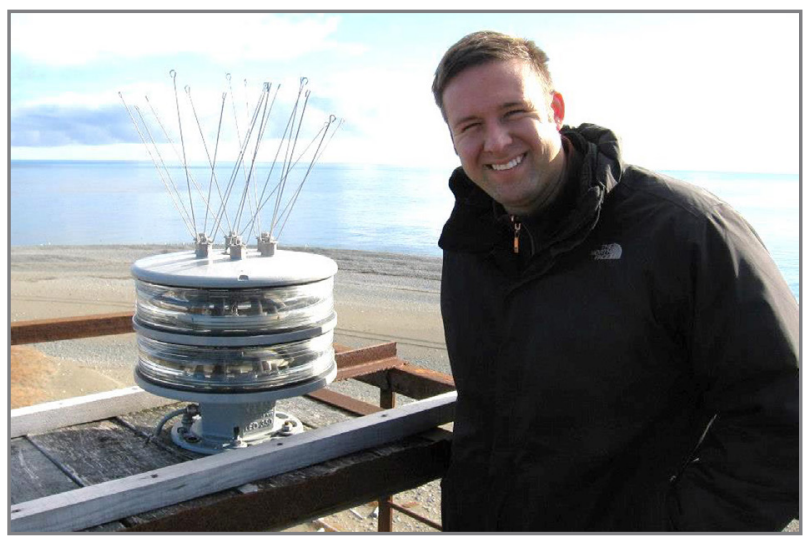

Nicholas Cavellero inspects a new solar-powered light beacon to signal ships traversing the Bering Sea between Russia and Alaska. NNSA partnered with Russia to replace the previous lighthouses that were powered by radioisotope thermoelectric generators.

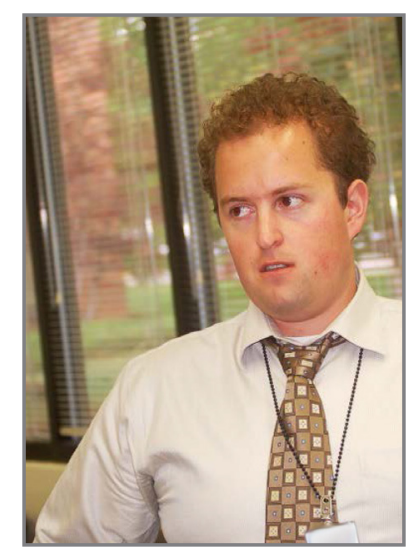

Kyle Hartig was honored to brief Secretary of Energy Dr. Steven Chu on his Ph.D. research in laser remote sensing.

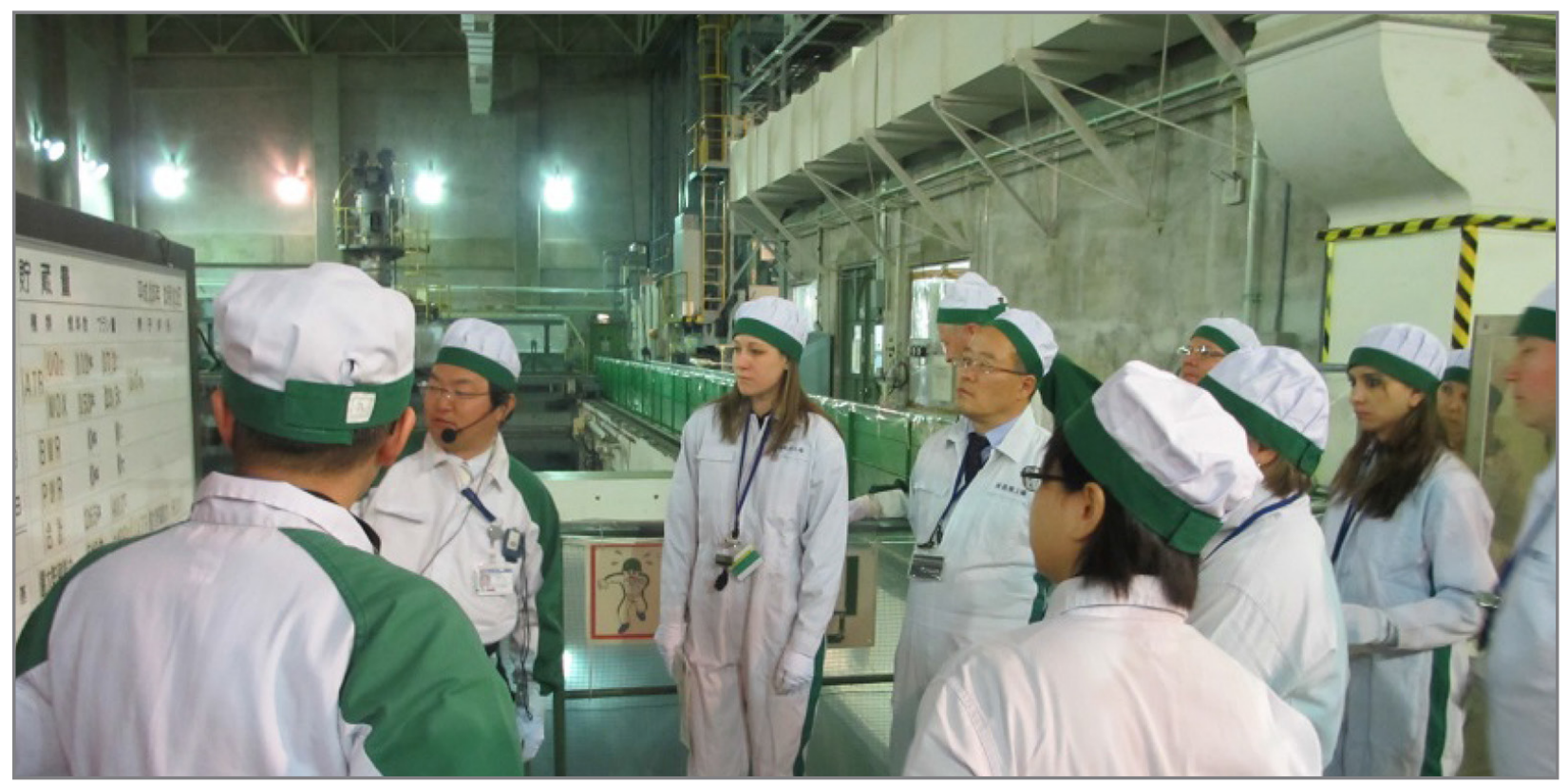

Rosalyn Leitch (third from left) visited the Tokai Reprocessing Plant in Japan. She was participating in an NNSA/Japan Atomic Energy Agency workshop focusing on advancements in safeguards technology for reprocessing. 
served as the NNSA point of contact for a multilaboratory tool to evaluate space-based nuclear detonation detection capabilities. Jonathan

Levinson assisted in preparing NNSA materials for FY 2014 Congressional budget briefings.

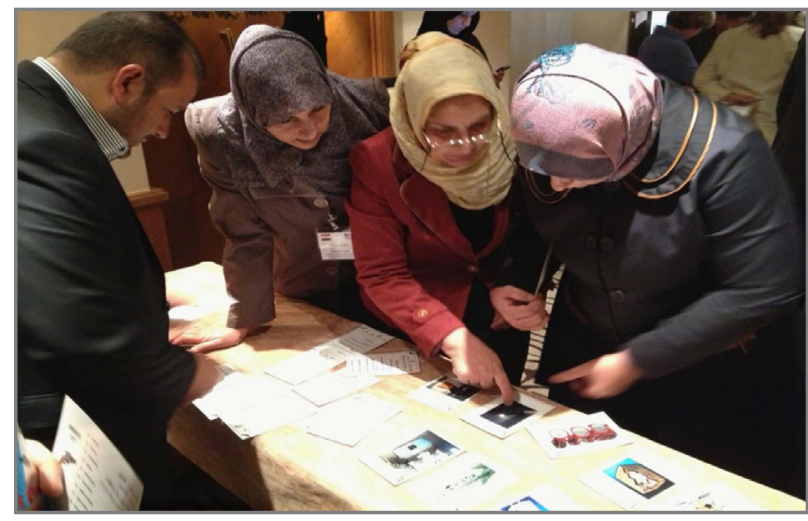

Daniel Miller (not shown), assigned to NNSA's International Nonproliferation Export Control Program, participated in the first-ever export control engagement with Iraqi enforcement officials.
Coming into this year, I was interested only in a narrow field, focusing on U.S. national security policy toward the Middle East and Iran. Over the past 12 months, however, I have been exposed to a diverse array of issues about which ... I have become passionate enough to dedicate my entire career. Based on this year, I have broadened my career prospects to include supporting counter-WMD terrorism, counter-nuclear trafficking and interdiction, nuclear security, and a number of other areas I had never previously considered. For this, I am grateful to the NGFP and for the support of my NNSA supervisors.

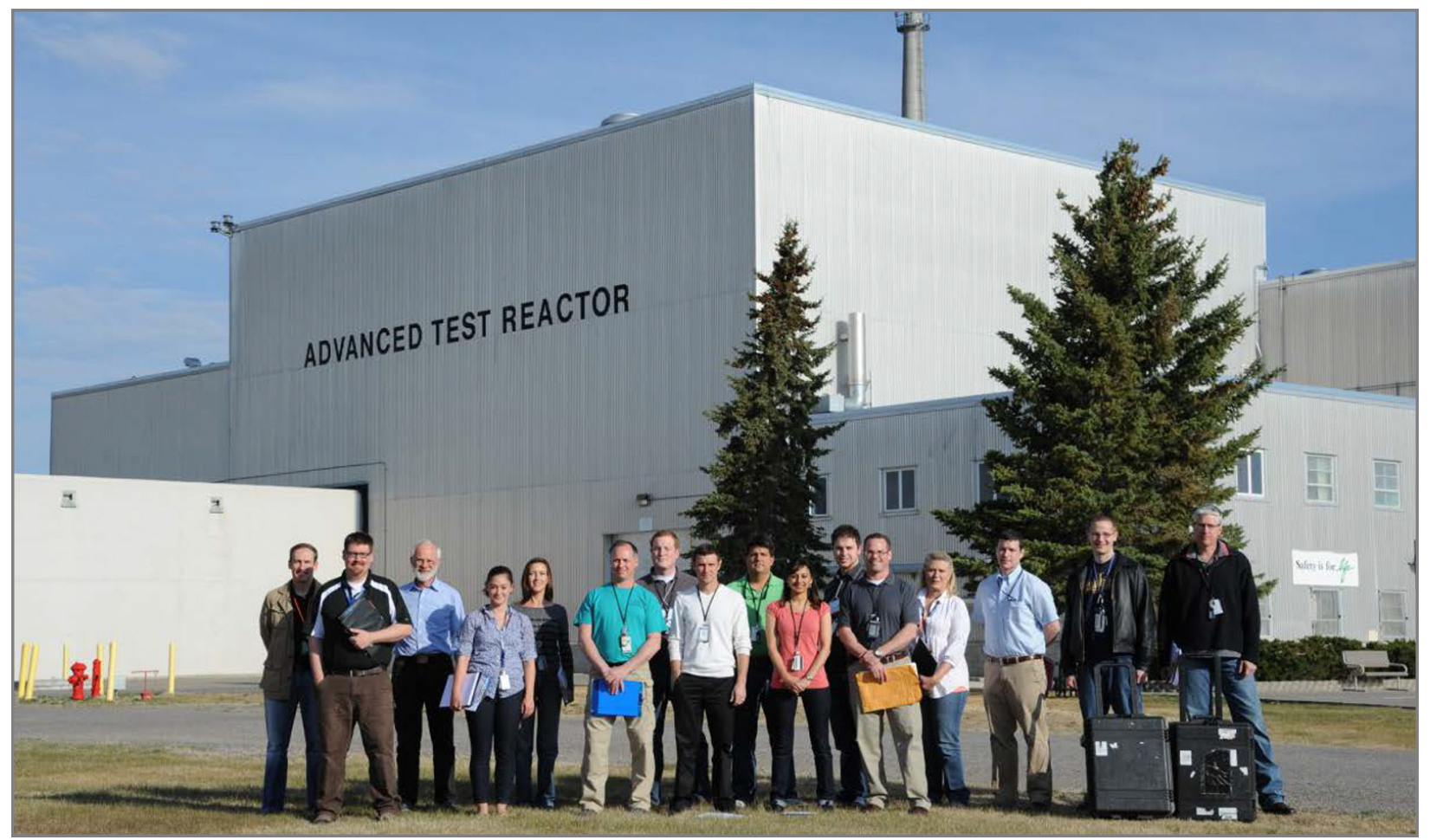

Fellows got a close look at the Advanced Test Reactor facility at the Idaho National Laboratory, where researchers study the effects of intense radiation on reactor materials and fuels. 


\section{Where They Are Now}

\section{Class of 2012}

NGFP alumni are highly sought after by employers in the nuclear security community. After completing their assignments, many Fellows from the Class of 2012 accepted positions where they continue to support the global security mission - whether in government, industry, the private sector, or academia. The list below shows where they were as of summer 2013.

Thomas Agee

Jared Carter

Nicholas Cavellero

Mara Cowan

Patrick Disney

Michelle Dover

Matthew Duchene

Courtney Gavitt

Mari Gillogly

Alison Goodsell

Kyle Hartig

Sonal Joshi

Daniel Kadishson

Rosalyn Leitch

Manuel Manriquez

Daniel Miller

Lindsay Minnema

Lauren Rutledge

Alicia Swift

David Vermillion

Zachary Whetstone
Laurence Lewis

$$
\begin{aligned}
& \text { NNSA - Support Services Contractor (MELE Associates) } \\
& \text { NNSA - Support Services Contractor (Culmen International) } \\
& \text { NNSA - Support Services Contractor (MELE Associates) } \\
& \text { NNSA - Support Services Contractor (MELE Associates) }
\end{aligned}
$$

U.S. Department of State, Bureau of International Security and Nonproliferation - Office of Cooperative Threat Reduction

James Martin Center for Nonproliferation Studies

Oak Ridge National Laboratory, University of Tennessee

NNSA - Support Services Contractor (Gryphon Scientific)

Oak Ridge National Laboratory

Los Alamos National Laboratory

Intelligence Community/U.S. Department of Defense

Pacific Northwest National Laboratory, University of Michigan

Office of the Deputy Mayor of New York City for Health and Human Services

Pacific Northwest National Laboratory

University of California Berkeley - Completing Degree

Japan Automobile Manufacturers Association, Inc.

U.S. Department of State, Bureau of International Security and Nonproliferation

U.S. Department of Energy, Office of Intelligence and Counterintelligence

U.S. Department of State - Support Services Contractor (LMI's Maintenance and Readiness Management Group)

Los Alamos National Laboratory

Oak Ridge National Laboratory, University of Tennessee

U.S. Government - Support Services Contractor (TASC, Inc.) and University of Michigan Completing Degree

As of Summer 2013, plans for Jonathan Levinson were pending. 


\section{Alumni Spotlight}

Including the class of 2012, 243 NGFP alumni have continued to apply their NNSA mission knowledge and experience worldwide since 1997. Here we proudly highlight two outstanding NGFP alumni from past years who have since risen to leadership positions: Kirsten McNeil and Dr. Clark Cully.

Kirsten McNeil - Class of 2009 - Foreign Affairs Specialist, NNSA's Office of Nonproliferation and International Security

Kristen McNeil began her NGFP fellowship in 2009 and never looked back. At the end of her term, NNSA hired her in the office of Nonproliferation and International Security. In

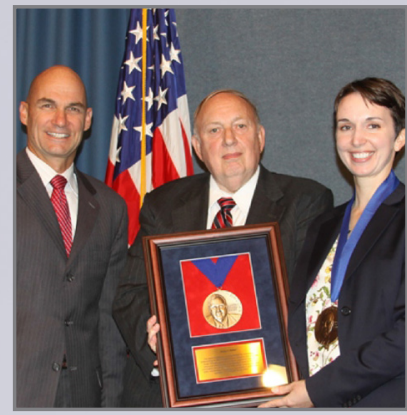

Kirsten McNeil proudly receives her award given by then-NNSA Administrator Tom D'Agostino (left) and Ambassador Linton Brooks (center).
2012 Linton Brooks Meda

for Dedication to Public

Service. The medal, named for former NNSA

Administrator Brooks, recognizes early-career employees whose actions and deeds exemplify the spirit of public service commitment.
In her current role, Kirsten was instrumental in developing a sustained effort to adapt a unique set of NNSA assets to support U.S. enforcement. Through these efforts, NNSA provides coordinated training and real-time technical reachback support for U.S. enforcement agencies.

She also serves as the lead point of contact between NNSA and all U.S. export enforcement agencies, creating strong working level interagency partnerships, and elevating the dual-use smuggling issue.

"During my NGFP term, working directly with representatives in other countries showed me how nonproliferation via international engagement actually happens," Ms. McNeil said. "Bringing this ground-level understanding back to headquarters operations was crucial to my development within NNSA." She added, "The NGFP experience helps put everything you may have read about or studied in graduate school into context, while giving you the opportunity to shape U.S. nonproliferation implementation."

\section{Dr. Clark Cully - Class of 2008 Policy Analyst, Office of Nuclear Policy, Office of the Secretary of Defense}

With a PhD in particle physics and a stint at the National Academy of Sciences working on international security and

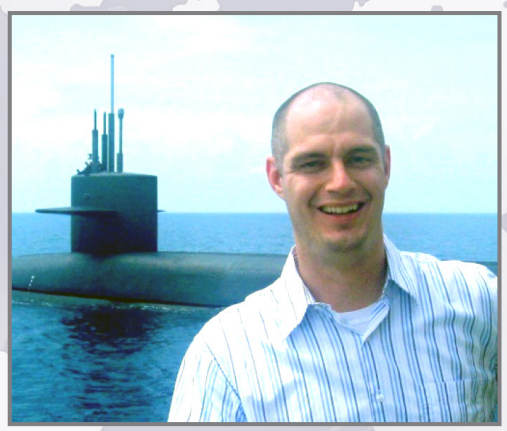

Dr. Clark Cully helps develop and implement U.S. nuclear policy.
After leaving NGFP, he was offered a rare opportunity to serve as a Presidential Management Fellow in the Office of Secretary of Defense. His work there included serving with NATO in Afghanistan, the Senate Appropriations Committee, and the Office of Defense Research and Engineering. His stellar performance led to a permanent position in the office of the Secretary of Defense, where he helps develop and implement U.S. nuclear policy. arms control, Dr. Clark Cully was an excellent fit for NGFP. As a 2008 Fellow in NNSA's Office of Nonproliferation Research and Development, he soon became familiar with technologies from handheld detectors to new satellites. "I really enjoyed learning the science and technology developments that underpin the national security enterprise," he said. "It was a great opportunity to learn program management, a rare skill for people my age."
Dr. Cully's time as an NGFP Fellow cemented his destiny as a career civil servant in pursuit of global security. "NGFP taught me the fundamentals for success in the executive branch, such as developing requirements, budgeting, program evaluation, Congressional engagement, and partnering with other agencies," he said. "The program put my career on a solid trajectory that shapes what I do today." 


\section{Appendix: \\ Class of 2012 Biographies}




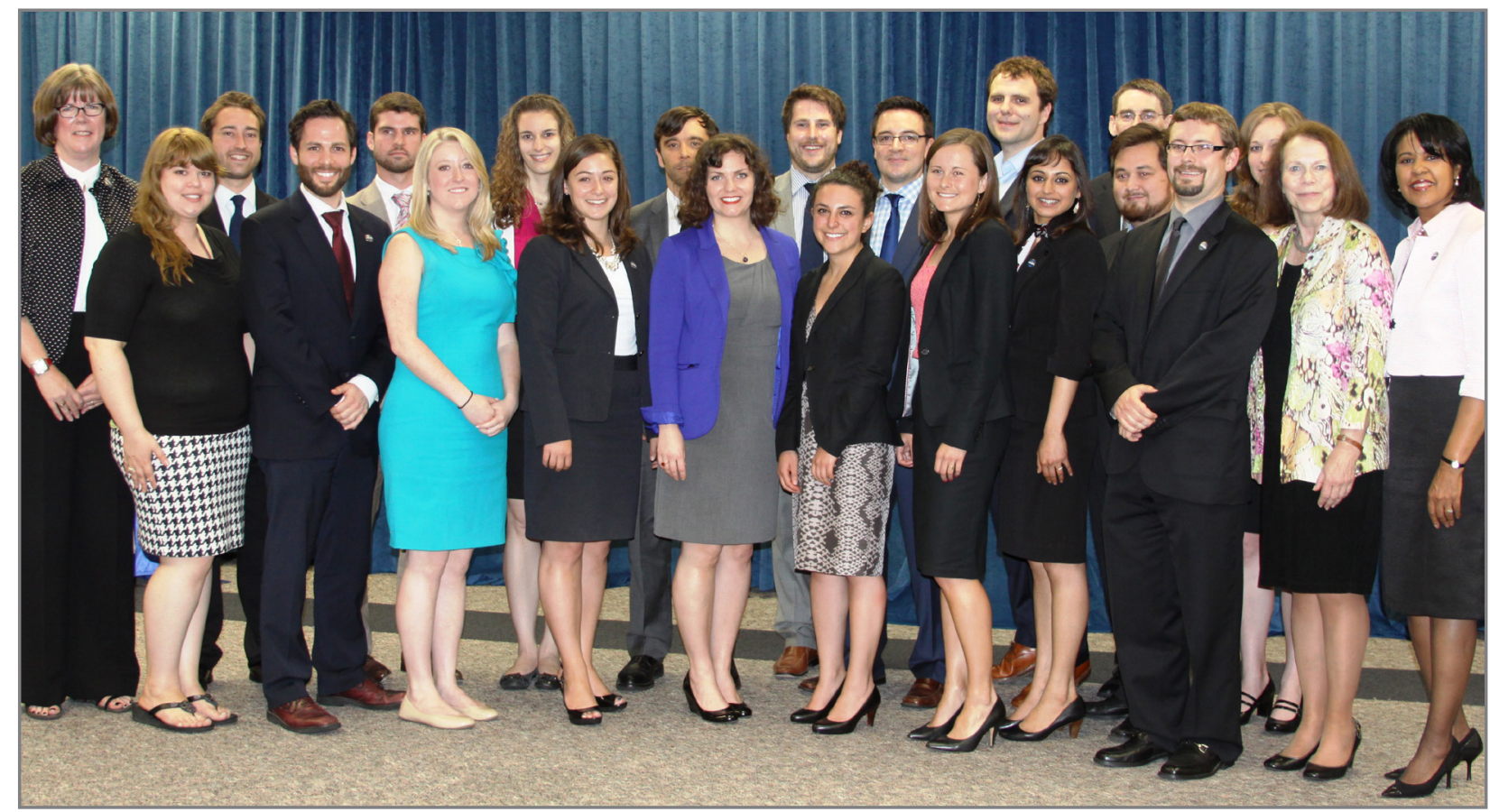

The Class of 2012, here with their leaders and mentors, gathers to celebrate their accomplishments at the end of their year. 


\section{Appendix Class of 2012 Biographies}

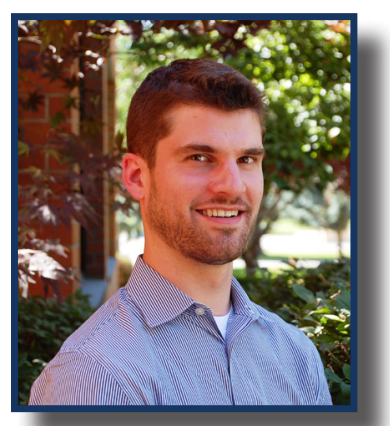

\section{Thomas Agee \\ Office of Global Threat Reduction North and South American Threat Reduction}

While completing his master's degree in international affairs-international security studies from The Elliott School of International Affairs at George Washington University, Thomas focused his coursework and projects on transnational security issues. His professional work experiences have focused on the consequence management aspects of nuclear/radiological proliferation issues.

Since 2010, Thomas worked as a program assistant for the Center for Radiological Emergency Management at the U.S. Environmental Protection Agency, where he helped develop strategies and training programs for radiological emergency response, evaluated radiation homeland security and emergency response assets and capabilities, and researched international and domestic radiation safety standards and initiatives.

Prior to his work at the Environmental Protection Agency, Thomas served as a legislative intern in the Texas House of Representatives, working with state and federal agencies to manage constituent casework and research issues for legislative action. Previously, he conducted international market research and provided export assistance for North Texas businesses at the U.S. Department of Commerce. Thomas is fluent in Spanish and holds numerous emergency management training certifications from the Federal Emergency Management Agency.

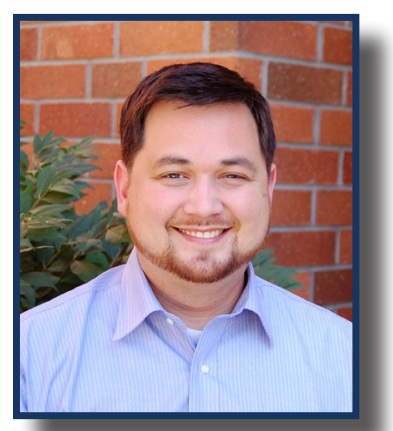

\section{Jared Carter \\ Office of the Second Line of Defense - Megaports}

After receiving a bachelor's degree in political science from the University of Maine, Jared Carter completed his master's degree in international affairs from Texas A\&M University, Bush School of Government and Public Service, concentrating on defense and nonproliferation. There, he served on the Texas A\&M chapter's executive council for the Institute of Nuclear Materials Management where he helped plan and execute an international workshop on insider threats.

For the Texas A\&M Nuclear Security Science and Policy Institute, Arms Control and Verification research group, Jared conducted research for the United Kingdom - Norway Initiative and warhead disarmament verification methodology. After graduation, Jared received a research grant directed at finding and disseminating effective reconstruction and development methodologies for military, government, and nongovernment organizations, funded by the Borlaug Institute's H.G. Buffet Center for Conflict and Development.

Jared attended the Middlebury's Katharine Davis School of Russian Immersion Program where he developed a working knowledge of Russian. Jared has spent three years working abroad.

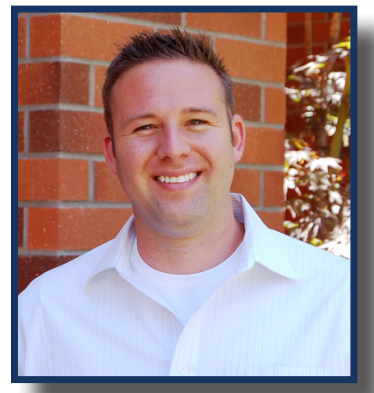

\section{Nicholas Cavellero} Office of Former Soviet Union and Asian Threat Reduction

Nicholas completed a master of international affairs degree from Columbia University School of International and Public Affairs in 2012, with a concentration in international security policy. 
After graduating with honors from The Citadel, the Military College of South Carolina, with his bachelor of science degree in business administration, Nicholas spent approximately five years working in finance and consulting in the private sector, with one of those years living and working in the former Soviet Union Republic of Kyrgyzstan and visiting Russia, Kazakhstan, Uzbekistan, and Tajikistan.

During his employment in Kyrgyzstan, Nicholas supervised a team of 10 foreign national employees and led more than 30 project teams annually in developing financial models, conducting valuation analysis, and making strategic recommendations for clients in defense and other industries. He successfully sourced over $\$ 9$ million in funding for anti-terrorism, anti-narcotics, and anti-weapons proliferation border security projects for the Kyrgyz Republic. These projects required Nicholas, who is proficient in Russian, to facilitate coordination between officials at the U.S. Department of State, the Kyrgyz government, and the U.S. Air Force Transit Center at Manas.

Prior to that, Nicholas's experience includes sourcing over $\$ 2$ billion worth of financial transactions for companies in various industries. Nicholas is dedicated to a career in public service.

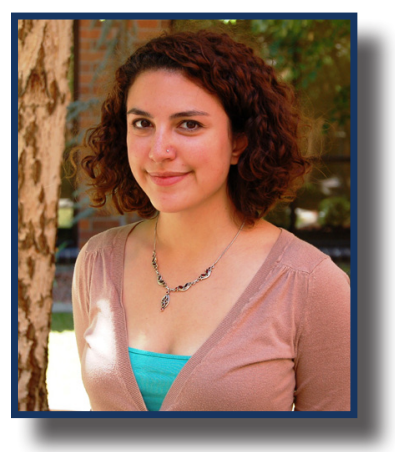

\section{Mara Cowan Office of European and African Threat Reduction}

Mara Cowan received a master's degree in Middle East studies in June 2012 from the University of Washington's Henry M. Jackson School of International Studies, as well as a certificate in international development policy and management from the University of Washington's Evans School of Public Affairs.

Mara received the Foreign Language and Area Studies Fellowship - Turkish during the academic years 2010-2012. In 2011, Mara interned with the Department of Defense's Office of Rule of Law and Detainee Policy as a Rosenthal Fellow, where she supported a variety of programs dealing with international humanitarian law and the Department's role in stability operations and security cooperation. She conducted research and drafted memoranda on issues such as improved civil-military coordination in post-disaster environments, minimizing and mitigating civilian harm during U.S. military and multilateral operations, and increasing training for personnel and contractors to observe the laws of war and respect international human rights.

Mara is proficient in Arabic and has a working knowledge of German and Turkish. She has lived, studied, and worked in countries as diverse as Canada, Oman, Germany, and Egypt.

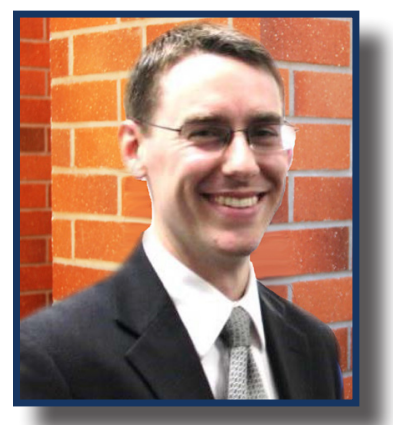

\section{Patrick Disney Office of Nonproliferation and International Security}

While completing his master's degree in international relations from Yale University in 2012, Patrick Disney focused on nuclear nonproliferation, doing extensive research on Iran's nuclear program, the U.S. nuclear testing program, the history of science advising in U.S. policy making, and the threat posed by electromagnetic pulse weapons. He received a certificate in International Nuclear Safeguards Policy and Information Analysis from the Monterey Institute of International Studies in 2011 and a bachelor's degree in political science from Trinity University in San Antonio in 2007.

As the Assistant Policy Director for the National Iranian American Council (2008 - 2010), Patrick engaged with policy makers and leading experts on critical issues involving nuclear proliferation and national security. He coordinated a coalition of more than 35 security and arms control organizations to advocate for effective nonproliferation policies on Iran, and frequently briefed government officials on policy matters as they arose. 
Patrick has developed a strong familiarity with U.S. nonproliferation strategies and export control regulations as a result of his work with Congress, and has honed his analytical skills by providing commentary to major media organizations. Over recent years, Patrick continued to provide in-depth analyses of nuclear issues, writing for The Atlantic, Foreign Policy, and The Nonproliferation Review. Patrick has a working knowledge of Persian (Farsi) and Spanish, and was a political/economic section intern at the U.S. Department of State, U.S. Embassy, in Muscat, Oman.

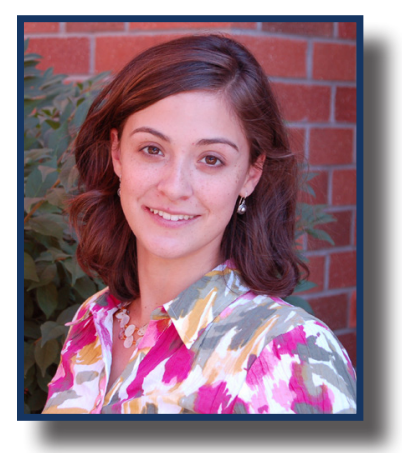

\section{Michelle Dover}

\section{Office of Nuclear Safeguards and Security, Safeguards Policy}

Michelle Dover received a master's degree in international peace and conflict resolution from American University's School of International Service in 2012. Before starting her graduate studies, she completed the International Safeguards Policy and Information Analysis intensive course offered by the Monterey Institute of International Studies and Lawrence Livermore National Laboratory in support of the Next Generation Safeguards Initiative. Michelle became proficient in French as an undergraduate exchange student at the Paris Institute of Polical Science.

As a research assistant at the James Martin Center for Nonproliferation Studies, Michelle conducted original research and wrote analyses of issues in nonproliferation, emerging chemical and biological weapon threats, and nuclear energy. Her work has appeared in publications including World Politics Review and The National Interest. Michelle interned at the United Nations Information Center in Washington, D.C., where she reported on government hearings and think tank briefings and assisted with United Nations events, outreach, and public inquiries.

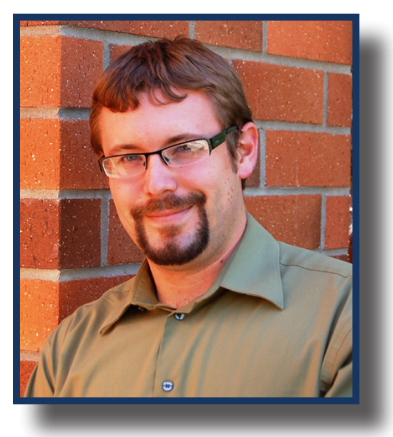

\section{Matthew Duchene Office of Nonproliferation Verification Research and Development}

Receiving his master's degree in nuclear engineering from the University of Illinois in May 2012, Matthew Duchene focused his academics on understanding the technical and policy issues related to nuclear nonproliferation. His thesis research examined how to better estimate time frames for state development of nuclear weapon programs.

Matthew served as a teaching assistant for a course on nuclear weapons and arms control from 2008 through 2012. His nonproliferation policy studies at Illinois led to a certificate in global security from the Program in Arms control, Disarmament, and International Security. He also participated in the international safeguards policy summer course at the Monterey Institute of International Studies.

Matthew complemented his academic experience with five summers of internships at national laboratories, getting hands-on experience with nuclear security and safeguards issues at facilities. These include four internships at Argonne National Laboratory from 2007 to 2010 and one at Savannah River National Laboratory in 2011. This work included thorium fuel cycle proliferation resistance, safeguards technology implementation in pyroprocessing, material control and accountability, lab work with nanoscale proportional counters, a feasibility study for a safeguards detector technology test bed, and research on modeling spent fuel dissolution. 


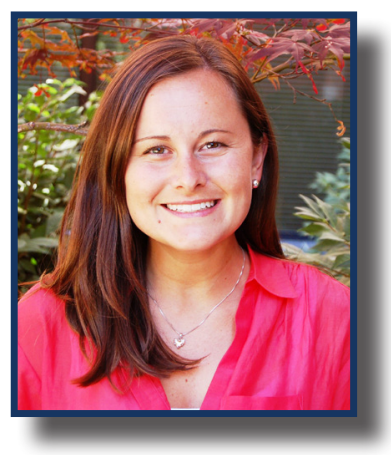

\section{Courtney Gavitt \\ Office of Nuclear Controls, Export Control Review and Compliance Team}

Courtney Gavitt is working toward her master's degree in Biodefense at George Mason University within the Department of Public and International Affairs. Scheduled for completion in December of 2013, her academic work incorporates the study of biological, chemical, and nuclear weapons technology with associated nonproliferation policy concerns. The program builds upon Courtney's undergraduate work in international studies and politics. She plans to continue her analysis of U.S. national security strategy to offer policy-relevant suggestions about how to better pursue America's national interests.

Courtney's career ambitions center on nonproliferation policy. She seeks to help safeguard existing weapons and to prohibit further proliferation through the development and enforcement of deliberate, global export controls.

Courtney's experience since February 2010 as a project analyst for a contractor to U.S. Customs and Border Protection has given her first-hand knowledge of transnational security threats. In this role, she supported the Border Patrol Facilities and Tactical Infrastructure program, providing Border Patrol with long-term technical solutions for border security challenges. Previously, she provided programmatic, budgetary, and proposal development support for a U.S. Agency for International Development program administered by The Academy for Educational Development in Washington, D.C. Before that, she created a financial education curriculum for use in Latin American communities for The Young Americas Business Trust. Courtney has a working knowledge of Spanish.

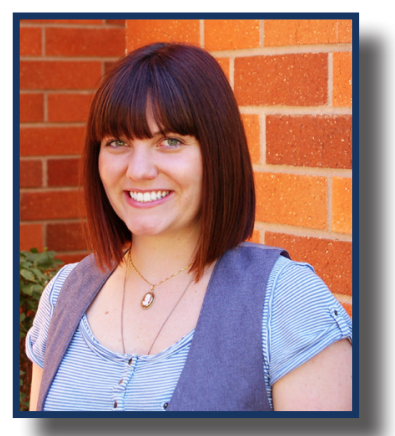

\section{Mari Gillogly \\ Office of Nuclear Safeguards and Security Safeguards Engagement}

While pursuing a master's degree in nonproliferation and international security at King's College London, Mari Gillogly focused her studies on nuclear weapons proliferation; treaty verification; trafficking of nuclear knowledge, materials, and technology; and U.S./Russian foreign policy on ballistic missile defense and tactical nuclear weapons.

Within the college's War Studies department, Mari co-founded the King's chapter of Students for International Security, a group that conducted focused discussions and collaborated with academic and subject matter experts on nuclear weapons policy and strategy. In 2011, Mari participated in a multi-lateral exercise in Oslo, Norway to monitor and verify the disarmament of a class of nuclear weapons nuclear and non-nuclear weapons states. She also completed the Eighth Annual Nuclear Safeguards and Nonproliferation course organized by the European Safeguards Research and Development Association in Uppsala, Sweden.

Complementing the international perspective of her studies, Mari interned in London in 2011 as assistant to Louis B. Susman, U.S. Ambassador to the United Kingdom, and his Deputy Chief of Mission, Barbara Stephenson. Additionally serving as political liaison on nonproliferation, deterrence, and defense, she provided research and analysis on all issues and correspondence related to chemical, biological, radiological, and nuclear weapons. Immediately following the completion of her degree in 2011, Mari worked as an intern at the King's College London Centre for Science and Security Studies with the Project on Proliferation Procurement, helping to develop a best practices guide on export controls for materials and technologies manufacturers in the United Kingdom's private sector. She has also studied numerous languages and has owned Agency M. Literary Services, Inc. since 2005, providing research, writing, and editing services for both the academic and creative markets. 


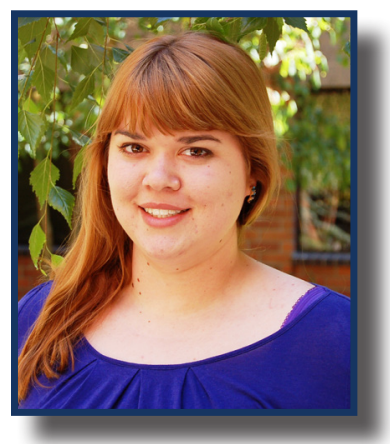

\section{Alison Goodsell \\ Office of Intelligence and Counterintelligence}

Alison Goodsell is working toward an August 2012 completion of her master's degree in nuclear engineering from Texas A\&M University. Her coursework there focused on nuclear nonproliferation, safeguards, and engineering.

As a graduate student, Alison worked for the Nuclear Security Science \& Policy Institute, studying fuel cycle safeguards, nonproliferation technologies, and international policy. Her master's thesis was on using the optical properties of quartz crystals for the nondestructive analysis of plutonium content within spent nuclear fuel. In 2011, Alison completed the International Nuclear Safeguards Policy course offered by the Monterey Institute for International Studies through Lawrence Livermore National Laboratory.

As an undergraduate, Alison gained international research experience in low-energy particle physics by supporting the Cryogenic Underground Observatory for Rare Events collaboration, traveling to the Gran Sasso National Laboratory in Assergi, Italy to assist in their experiment investigating neutrinoless double-beta decay. She received her undergraduate degree in physics from California Polytechnic State University.

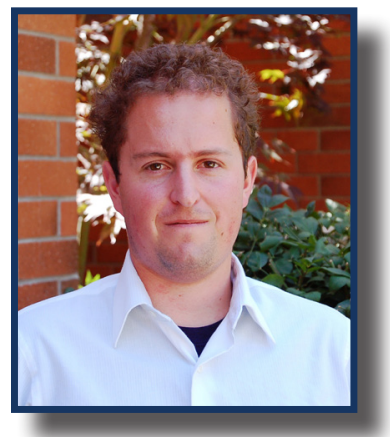

\section{Kyle Hartig \\ Office of Nuclear Safeguards and Security, Safeguards Technology}

In 2011 Kyle Hartig embarked on a four-year program to earn his doctorate degree in nuclear engineering at the Pennsylvania State University while minoring in computational science. His focus is nuclear forensics, nonproliferation, and remote sensing, specializing in remote detection of proliferation activities.

Kyle's current research is on laser induced breakdown spectroscopy using ultrashort high-intensity shaped laser pulses - a technique that will enable analysts to identify materials and their isotopic makeup with little to no sample preparation. Kyle participated in the 2010 Nuclear Fuel Cycle and Radiochemistry Fellowship summer program held at University of Nevada-Las Vegas in 2010 and sponsored by the U.S. Department of Energy. He is the current president of the Penn State student chapter of the Institute of Nuclear Materials Management, which addresses global security needs in nuclear forensics and nonproliferation.

Since 2011 Kyle has been a fellow in the Nuclear Forensics Graduate Fellowship program sponsored by the U.S. Departments of Homeland Security and Defense Threat Reduction Agency. For three summers from 2009 through 2011 Kyle worked as a nuclear engineer for the Department of Defense, conducting oversight of servicing and operations of submarine reactors at Naval Base Kitsap in Washington State.

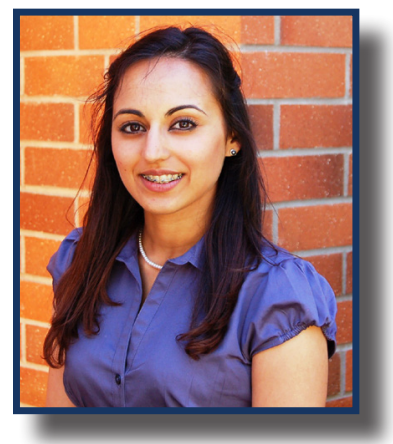

\section{Sonal Joshi Office of Nonproliferation Verification Research and Development}

Sonal Joshi is planning to graduate with her doctorate in nuclear engineering and radiological sciences from the University of Michigan in 2013. After completing her master's degree in engineering at the University of Michigan in 2010, she served as president and vice-president of the student chapter of the Institute of Nuclear Materials Management.

Sonal's current research into room-temperature semiconductor radiation detectors for homeland security and nonproliferation applications is funded by the U.S. Department of Homeland Security Domestic Nuclear Detection 
Office's Academic Research Initiative. Her specific project focuses on coded aperture gamma-ray imaging of sources in the energy range below $300 \mathrm{keV}$, useful for detecting special nuclear material while discriminating it from nonthreatening sources.

Sonal was selected to attend the summer course on Nuclear Nonproliferation, Safeguards, and Security at Brookhaven National Laboratory in 2009. Her undergraduate interest in radiation detectors and instrumentation led to two summer internships at Pacific Northwest National Laboratory in 2005 and 2006, where she analyzed detection technology advancements. She speaks Hindi and is equally comfortable in Indian and Western cultures.

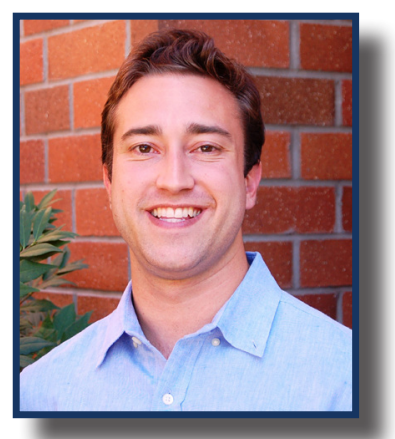

\section{Daniel Kadishson International Material Protection and Cooperation}

After obtaining his bachelor's degree in political science and international politics from Vassar College, Daniel Kadishson pursued his master's degree in international security studies at the National Defense University, expected to be completed in 2012.

He most recently served as a Congressional Analyst for the Deputy Assistant Secretary of the Army (Procurement), focusing on policy and oversight of contractors in Afghanistan and Iraq. In that position, he analyzed policy developments, led briefings for Army leadership, and coordinated across agencies to prepare Army leaders for Congressional engagements.

In 2010, Daniel served as Legislative Assistant to U.S. Congressman Phil Hare where he was the primary policy adviser on energy issues and assisted on foreign policy issues. In that role he also analyzed Iran sanctions and worked with House leadership and the U.S. Trade Representative on U.S.-China issues. He served as the liaison to the Nuclear Regulatory Commission and Exelon Quad-Cities Nuclear Power Plant, located in the congressional district. In 2008, for the Genocide Intervention Network, he analyzed and reported on developments in Sudan, the International Criminal Court and the United Nations.

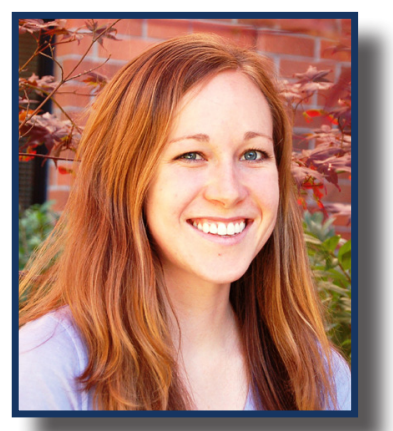

\section{Rosalyn Leitch} Office of Nuclear Safeguards and Security, Nuclear Security

Having served as a Security Specialist at the Nuclear Regulatory Commission since 2010, Rosalyn Leitch received her master's degree in security studies and nonproliferation from Georgetown University's Edmond A. Walsh School of Foreign Service in 2012. At the NRC, Rosalyn worked on physical security issues at both domestic and international nuclear facilities. She developed training and qualification guidelines for physical protection technical experts, as well as reviewed interagency reports on physical security measures at foreign nuclear facilities. Rosalyn is also qualified as an Emergency Response Official for emergencies involving NRC-licensed facilities and material.

After completing her undergraduate degree in International Relations at Seattle Pacific University, Rosalyn worked at the U.S. Civilian Research and Development Foundation, assisting the nonproliferation team with project implementation, grant and contract execution, and proposal writing. She also provided logistical support for nuclear security programs of the U.S. Department of State, and led a dynamic simulation activity on fuel cycle objectives and nuclear infrastructure development.

Rosalyn completed internships at Los Alamos National Laboratory in nonproliferation policy; at the U.S. Department of State in Moscow, Russia, in the Office of Environment, Science, and Technology; and at World Vision International. Rosalyn has international experience in 11 countries, is proficient in French, and has a working knowledge of Spanish. 


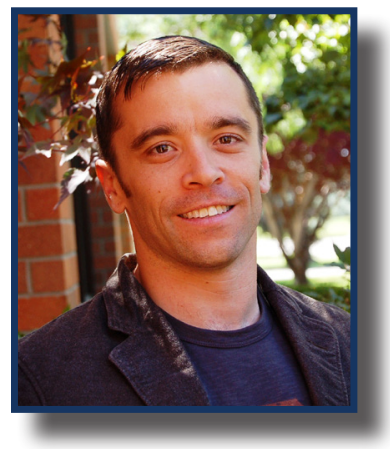

\section{Jonathan Levinson \\ Office of Defense Nuclear Nonproliferation}

Jonathan Levinson received his master's degree in international affairs - international security policy from Columbia University School of International and Public Affairs in May 2012. His core studies were focused on the Middle East and the increasing importance of non-state actors in the region.

After receiving his undergraduate degree in political science from the University of California, Davis, Jonathan served five years in the U.S. Army as an infantry officer and deployed twice to Iraq. He led a 35-man infantry platoon in Iraq from 2006-2007, where he experienced the destabilizing impact of chemical, biological, radiological, and nuclear threats. Later, as a staff officer responsible for the logistics of a 1,000-man task force, he coordinated and oversaw some of the first U.S. base closures in northern Iraq.

Jonathan has applied this operational experience to his academic pursuits, which included analyzing regional military capabilities in the Middle East and the consequences of weapons proliferation. Jonathan is proficient in Arabic and has a working knowledge of Spanish. He has lived and worked in the Middle East, including Libya, Yemen, the West Bank and Gaza, as well as Afghanistan and Turkey.

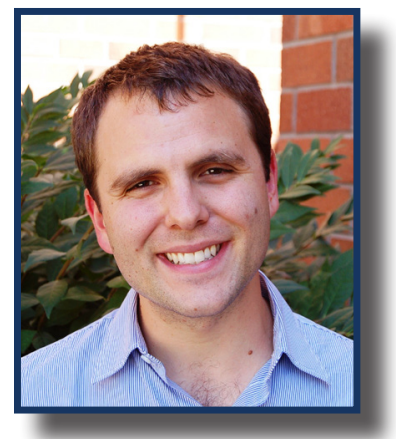

\section{Laurence Lewis Office of European and African Threat Reduction}

Since 2009 Laurence Lewis has been a graduate student researcher in nuclear forensics at Lawrence Livermore National Laboratory. Laurence's thesis work focused on analyzing nuclear fallout debris to help understand how nuclear fallout forms and distributes after a nuclear explosion. He has collected, analyzed, and presented data to brief policymakers on scientific developments that advance nuclear security. Laurence completed his master's degree in nuclear engineering at the University of California, Berkeley, in 2012. His coursework encompassed national security policy, the nuclear fuel cycle, nuclear physics, and energy and weapons policy. In 2011, Laurence was awarded an NNSA Nuclear Nonproliferation International Safeguards Fellowship as well as a Nuclear Regulatory Commission Graduate Fellowship.

Laurence's work in nuclear forensics and security is complemented by extensive time spent overseas including 10 years living in Saudi Arabia and three years in Indonesia.

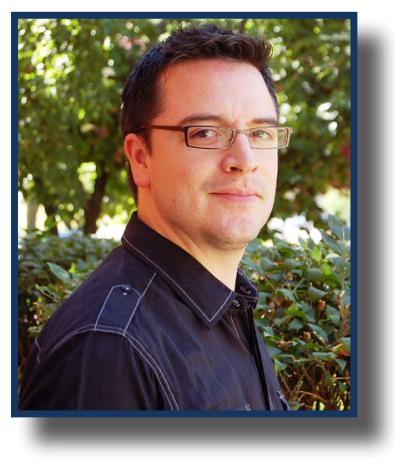

\section{Manuel Manriquez Office of Nuclear Controls Global Initiatives for Proliferation Prevention Team}

Manuel Manriquez earned his master's degree in May 2012 from the Edmund A. Walsh School of Foreign Service's Security Studies Program at Georgetown University, where he studied international security with a focus on nuclear weapons issues/ nonproliferation and East Asian security. During his time at Georgetown, Manuel also received a graduate certificate in Asian studies and served as the Foreign Languages and Area Studies Fellow for Japan studies during the 2011-2012 academic year.

As a graduate student, Manuel served as an intern with the Japan Chair Program at the Center for Strategic and International Studies (CSIS) in Washington, D.C., and participated in the CSIS Pacific Forum's Council for Security Cooperation in the Asia Pacific WMD Study Group in Ho Chi Minh City, Vietnam. He also participated in the Critical Languages Scholarship program in Kyoto, Japan, and the Japan Travel Program for Future U.S. Leaders in Tokyo. 
Additionally, Manuel served as the communications director and a founding board member of the International Security Forum, where he organized panel discussions featuring various security practitioners and specialists.

While earning his bachelor's degree in political science and Asian studies at the University of California, Berkeley, Manuel was a research intern at the James Martin Center for Nonproliferation Studies, where he collaborated with nonproliferation and East Asia experts on analysis of security issues in the region. After earning his undergraduate degree, he interned for Congressman Martin Heinrich of New Mexico's 1st District. To date, Manual has published several works on East Asian and Japanese security issues as well as nuclear weapons issues. He is proficient in Japanese and has a working knowledge of Spanish.

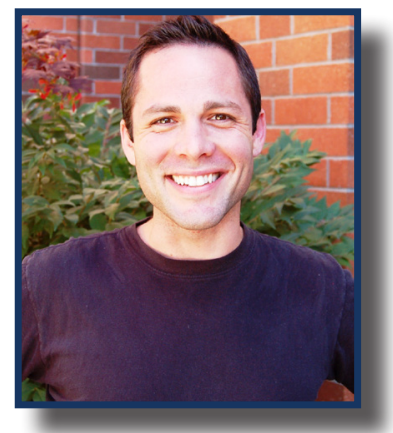

\section{Daniel Miller Office of Nuclear Controls, International Nonproliferation Export Control Program}

Since 2011, Daniel Miller has been working as an intern in the Office of Russian and Eurasian Affairs in the U.S. Department of Energy Office of Policy and International Affairs, where he contributes to the Near-Zero Zone project, a model industrial energy efficiency project in Turkey. His work covers a host of issues related to the region, including cooperation on bilateral nuclear security initiatives in Russia, Kazakhstan, Turkey and Israel. Daniel received his master's degree in Eurasian, Russian, and East European Studies in 2011 from Georgetown University, School of Foreign Service in Washington, D.C.

Through his regionally focused graduate coursework, Daniel has researched and written extensively on topics directly related to energy and nuclear security issues throughout Turkey, Russia, the Caucasus, and Central Asia.

In 2010, Daniel interned at the U.S. Department of State in the Office of South Central European Affairs, where his responsibilities included tracking interethnic violent incidents in Kosovo for senior staff members. Daniel also interned in the Political/Economic Affairs Section, U.S. Consulate General in Istanbul, Turkey, where he drafted cables on Turkish domestic politics, nuclear security, and energy issues. Daniel is proficient in Turkish.

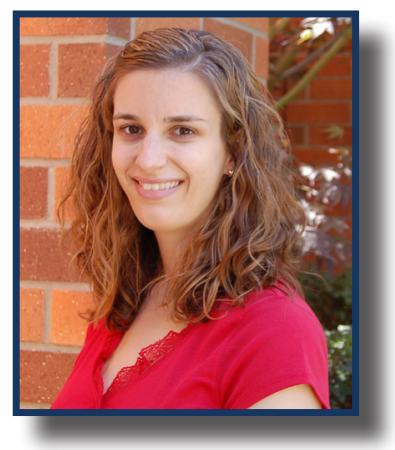

\section{Lindsay Minnema Office of Nuclear Controls, International Nonproliferation Export Control Program}

Lindsay Minnema graduated in 2012 from the University of Michigan Gerald R. Ford School of Public Policy with a master of public policy and a focus on international security and defense policy.

Lindsay holds a degree in journalism from Northwestern University and worked as an editor for three years at The Washington Post. As a part of her undergraduate program, she studied European Union monetary and defense policies at the Danish Institute for Study Abroad, Copenhagen, also participating in field studies in Belgium, The Netherlands, and Russia.

In 2011 Lindsay interned with the International Narcotics Control Board in the United Nations Office on Drugs and Crime in Vienna, Austria, where she researched and assessed monetary outlays for drug control programs in Afghanistan. She analyzed policy topics on export control, interdiction, customs and law enforcement, and promotion of licit drug development. While there she leveraged her journalistic skills by preparing backgrounders and briefing materials for use by Board members and staff during official missions. She also researched and prepared materials on Western European policy developments, drug seizures, trafficking trends, organized crime, and Europol activities. 


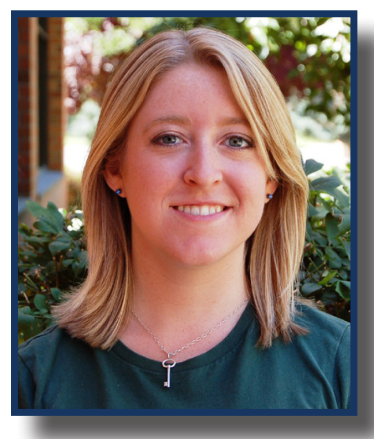

\section{Lauren Rutledge \\ Office of Management and Budget}

Lauren Rutledge is on track to graduate in 2013 with her master's in public administration from the Trachtenberg School of Public Policy and Public Administration at The George Washington University. She is specializing in national security and nuclear weapons policy. Lauren also holds a bachelor's degree in communication studies and political science from the University of Miami. She has written for The George Washington University's policy journal.

Lauren is a public policy and administration professional with three years of experience in public affairs communications, research, and policy analysis. Her most recent research has involved NATO's nuclear sharing program and analysis of policy options to denuclearize North Korea. She worked as a press and communications intern in various U.S. Senate and House offices.

In 2010, she served as a speechwriting intern in the White House, Executive Office of the President, researching speech content and contributing to Presidential remarks.

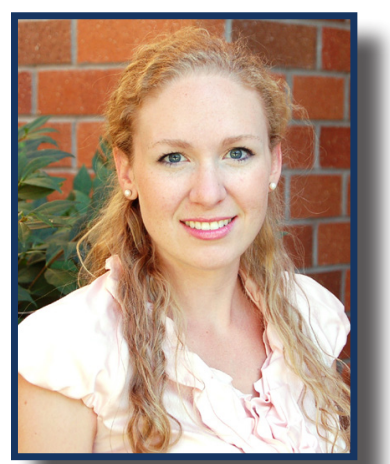

\section{Alicia Swift Office of North and South American Threat Reduction}

Alicia is a PhD candidate in nuclear engineering from the University of Tennessee, Knoxville. She received her master's degree in nuclear engineering and her Certificate in Nuclear Security Science and Analysis from the University of Tennessee, Knoxville in May, 2012. While obtaining her bachelor's degree in nuclear engineering and minor in physics from the University of Florida, she conducted detector monitoring experiments designed to prevent the smuggling of illicit nuclear materials in shipping containers. She also performed analytical modeling of the Calder Hall reactor, a discontinued gas-cooled, graphite-moderated British reactor, and helped design a pool-type reactor for the production of medical isotopes.

For the past year Alicia has conducted graduate research at Oak Ridge National Laboratory, where she has been determining the limits and accuracy of an attribute determination procedure for the Nuclear Materials Identification System, which actively interrogates and images unknown objects for possible future nuclear treaty verification applications. She also led 20 people as part of a tabletop counter-terrorism exercise for nuclear security that was conducted at the Y-12 National Security Complex in collaboration with the University of Tennessee, Knoxville.

In addition to her expertise with parallel processing nuclear transport computer codes, Alicia speaks and reads Spanish and French.

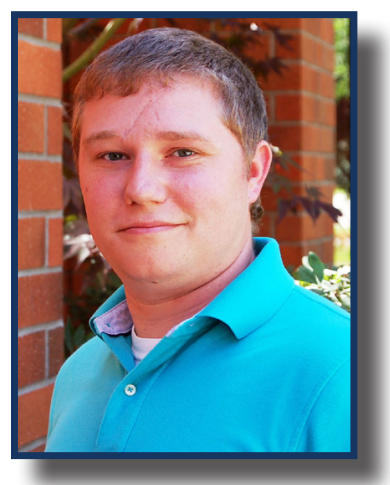

\section{David Vermillion Office of Nonproliferation Verification Research and Development}

David received his master's degree in nuclear engineering in 2012 from the University of Tennessee and is planning to pursue a PhD in nuclear engineering. He holds a certification in nuclear security science and analysis from that university.

David interned at Oak Ridge National Laboratory (ORNL) since 2004 and is familiar with various radiation transport modeling, nuclear transmutation, and commercial U.S. nuclear reactor design codes. As a graduate student, David collaborated with 
engineers and scientists at ORNL and the Y-12 National Security Complex to design prototype gamma-ray equivalent radiation sources that simulate highly enriched uranium. These sources could eventually be used to better evaluate the radiation detection capabilities and standardize aspects of sources used in the nuclear detection industry.

While an undergraduate in nuclear engineering at the University of Tennessee, David spearheaded the foundation of Institute of Nuclear Material Management student chapter and was the vice president of the student American Nuclear Society. He was a cooperative education student with Southern Nuclear Company from 2006-2009, where he developed pragmatic nuclear core designs for their reactors and served as a reactor engineer at Plant Vogtle. David's research interests are focused on developing new technology and methods for nuclear power while simultaneously strengthening nuclear material security.

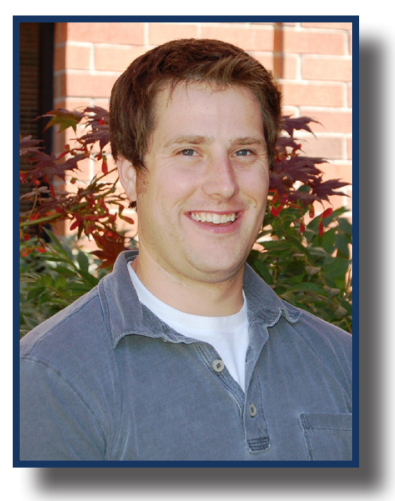

\section{Zachary Whetstone} Office of Nonproliferation Verification Research and Development

Zachary Whetstone is a $\mathrm{PhD}$ candidate in nuclear engineering and radiological sciences at the University of Michigan, with a radiation detection concentration. Zachary completed his master's and bachelor's degrees in nuclear engineering at the University of Michigan, with a concentration in health physics.

Most recently, Zachary served as a Nuclear Nonproliferation International Safeguards Fellow through the Department of Energy National Nuclear Security Administration. He was a Nuclear Nonproliferation Safeguards and Security scholar at Brookhaven National Laboratory in 2009, and was awarded a Department of Homeland Security fellowship from 2006 to 2009. Zachary has experience with public policy and nuclear nonproliferation through courses at the University of Michigan School of Public Policy and from his internships at the Lawrence Livermore National Laboratory and Brookhaven National Laboratory.

Zachary has served on several local and national society committees, has worked as a graduate student instructor, and has authored numerous journal articles and other publications. 


\section{DISCLAIMER}

This report was prepared as an account of work sponsored by an agency of the United States Government. Neither the United States Government nor any agency thereof, nor Battelle Memorial Institute, nor any of their employees, makes any warranty, express or implied, or assumes any legal liability or responsibility for the accuracy, completeness, or usefulness of any information, apparatus, product, or process disclosed, or represents that its use would not infringe privately owned rights. Reference herein to any specific commercial product, process, or service by trade name, trademark, manufacturer, or otherwise does not necessarily constitute or imply its endorsement, recommendation, or favoring by the United States Government or any agency thereof, or Battelle Memorial Institute. The views and opinions of authors expressed herein do not necessarily state or reflect those of the United States Government or any agency thereof.

\section{PACIFIC NORTHWEST NATIONAL LABORATORY}

operated by

BATTELLE

for the

UNITED STATES DEPARTMENT OF ENERGY

under Contract DE-AC05-76RL01830 
Program Administered by

Pacific Northwest National Laboratory

\section{Pacific Northwest}

NATIONAL LABORATORY

Proudly Operated by Battelle Since 1965

Manuel Gonzalez

Federal Program Manager

National Nuclear Security Administration

Office of Leadership and Career Management

Office of Management and Budget

(206) 586-2061

Jana Fankhauser, PNNL Program Manager

Pacific Northwest National Laboratory

ngp@pnnl.gov

(206) 528-3264

Learn about the NNSA Graduate Program

at http://ngp.pnnl.gov 